\title{
Development of a Mouse Reporter Strain for the Purinergic $\mathrm{P}_{2} \mathrm{X}_{2}$ Receptor
}

\author{
Seol-Hee Kim, Parmvir K. Bahia, Mayur Patil, Sydney Sutton, Isobel Sowells, Stephen H. Hadley, \\ Marian Kollarik, and Thomas E. Taylor-Clark
}

https://doi.org/10.1523/ENEURO.0203-20.2020

Molecular Pharmacology \& Physiology, Morsani College of Medicine, University of South Florida, Tampa, FL 33612

\begin{abstract}
The ATP-sensitive P2X $\mathrm{X}_{2}$ ionotropic receptor plays a critical role in a number of signal processes including taste and hearing, carotid body detection of hypoxia, the exercise pressor reflex and sensory transduction of mechanical stimuli in the airways and bladder. Elucidation of the role of $\mathrm{P} 2 \mathrm{X}_{2}$ has been hindered by the lack of selective tools. In particular, detection of $\mathrm{P}_{2} \mathrm{X}_{2}$ using established pharmacological and biochemical techniques yields dramatically different expression patterns, particularly in the peripheral and central nervous systems. Here, we have developed a knock-in $\mathrm{P} 2 \mathrm{X}_{2}$-cre mouse, which we crossed with a cre-sensitive tdTomato reporter mouse to determine $\mathrm{P} 2 \mathrm{X}_{2}$ expression. $\mathrm{P} 2 \mathrm{X}_{2}$ was found in more than $80 \%$ of nodose vagal afferent neurons, but not in jugular vagal afferent neurons. Reporter expression correlated in vagal neurons with sensitivity to $\alpha, \beta$ methylene ATP $\left(\alpha \beta\right.$ mATP). P2X $\mathrm{X}_{2}$ was expressed in $75 \%$ of petrosal afferents, but only $12 \%$ and $4 \%$ of dorsal root ganglia (DRG) and trigeminal afferents, respectively. P2X $\mathrm{X}_{2}$ expression was limited to very few cell types systemically. Together with the central terminals of $P 2 X_{2}$-expressing afferents, reporter expression in the CNS was mainly found in brainstem neurons projecting mossy fibers to the cerebellum, with little expression in the hippocampus or cortex. The structure of peripheral terminals of $\mathrm{P}_{2} \mathrm{X}_{2}$-expressing afferents was demonstrated in the tongue (taste buds), carotid body, trachea and esophagus. P2X $\mathrm{X}_{2}$ was observed in hair cells and support cells in the cochlear, but not in spiral afferent neurons. This mouse strain provides a novel approach to the identification and manipulation of $\mathrm{P} 2 \mathrm{X}_{2}$-expressing cell types.
\end{abstract}

Key words: ATP; P2X2; reporter mouse; sensory neurons; tracing

\section{Significance Statement}

Inhibitor and knock-out studies have demonstrated the critical role of $\mathrm{P}_{2} \mathrm{X}_{2}$ in multiple sensory signaling pathways. Nevertheless, $\mathrm{P}_{2} \mathrm{X}_{2}$ expression patterns are controversial, as biochemical studies suggest widespread expression, whereas functional studies suggest restricted expression. Functional characterization is further complicated by heteromeric $\mathrm{P}_{2} \mathrm{X}_{2 / 3}$ channels that have hybrid pharmacology and biophysical properties. We have developed a $\mathrm{P} 2 \mathrm{X}_{2}$-cre mouse to determine the expression pattern of $\mathrm{P} 2 \mathrm{X}_{2}$. In the periphery, $\mathrm{P} 2 \mathrm{X}_{2}$ expression is found in almost all nodose sensory afferents but is limited to only minor subsets of trigeminal and DRG afferents. Centrally, $\mathrm{P}_{2} \mathrm{X}_{2}$ is mostly expressed in neurons projecting mossy fibers to the cerebellum. Thus, we provide novel evidence for the specific expression of $\mathrm{P} 2 \mathrm{X}_{2}$, which is more limited than previously thought.

\section{Introduction}

$\mathrm{P} 2 \mathrm{X}_{2}$ is one of seven members of the P2X purinergic receptor family (Brake et al., 1994; Dunn et al., 2001; Khakh

Received May 19, 2020; accepted July 3, 2020; First published July 15, 2020.

The authors declare no competing financial interests. et al., 2001). P2X 2 is a cation-permeable plasma membrane ion channel activated by extracellular ATP, which

Author contributions: M.K. and T.E.T.-C. designed research; S.-H.K., P.K.B., M.P., S.S., I.S., S.H.H., M.K., and T.E.T.-C. performed research; S.-H.K., P.K.B., M.P., S.S., I.S., S.H.H., M.K., and T.E.T.-C. analyzed data; S.-H.K., P.K.B., M.P., M.K., and T.E.T.-C. wrote the paper. 
can form either functional homomeric channels or func-

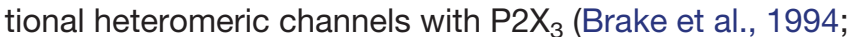
Chen et al., 1995; Lewis et al., 1995). Based on pharmacological and genetic knock-out studies, $\mathrm{P} 2 \mathrm{X}_{2}$ plays important roles in a number of peripheral organs, including taste cell signaling to gustatory sensory afferents (Finger et al., 2005; Huang et al., 2011), hypoxic signaling in carotid bodies (Rong et al., 2003), protection from noiseinduced ototoxicity (Yan et al., 2013), the exercise pressor reflex (McCord et al., 2010), and mechanical transduction in sensory afferents innervating the airways (Weigand et al., 2012) and bladder (Cockayne et al., 2005). Nevertheless, the precise role of $P 2 X_{2}$ in peripheral afferents and in other systems is hindered by the lack of selective tools.

$\mathrm{P} 2 \mathrm{X}_{2}$ and $\mathrm{P} 2 \mathrm{X}_{3}$ homomeric channels can be discriminated by the desensitization of their ATP-evoked currents (limited desensitization/persistent currents for $\mathrm{P}_{2} \mathrm{X}_{2}$ channels, rapid desensitization for $\mathrm{P} 2 \mathrm{X}_{3}$ ) and their sensitivity to $\alpha, \beta$ methylene ATP $\left(\alpha \beta\right.$ mATP; $\mathrm{P}_{2} \mathrm{X}_{3}$ is activated by this ATP analog, whereas P2X $X_{2}$ is not; Dunn et al., 2001; Khakh et al., 2001). Nevertheless, co-expression of P2X and $\mathrm{P}_{2} \mathrm{X}_{3}$ causes the formation of heteromeric $\mathrm{P} 2 \mathrm{X}_{2 / 3}$ channels that evoke mixed/persistent currents in response to both ATP and $\alpha \beta$ mATP (Lewis et al., 1995). Furthermore, the kinetics of P2X channel desensitization are modulated by numerous factors (Bianchi et al., 1999; Sokolova et al., 2006), thus decreasing its effectiveness as a diagnostic for discriminating $\mathrm{P} 2 \mathrm{X}_{2}, \mathrm{P} 2 \mathrm{X}_{3}$, and $\mathrm{P} 2 \mathrm{X}_{2 / 3}$ channels. Biochemical detection of $\mathrm{P} 2 \mathrm{X}_{2}$ reveals similar inconsistencies: immunohistochemistry and in situ hybridization has revealed robust and widespread expression of P2X $\mathrm{X}_{2}$ in peripheral and central neurons and smooth muscle (Brake et al., 1994; Kidd et al., 1995; Collo et al., 1996; Vulchanova et al., 1996; Kanjhan et al., 1999; Petruska et al., 2000b; Yao et al., 2000, 2003; Gourine et al., 2003; Spehr et al., 2004; Ambalavanar et al., 2005; Cockayne et al., 2005; Simonetti et al., 2006; Staikopoulos et al., 2007; Song et al., 2012), although functional studies of ATP- and $\alpha \beta$ mATP-evoked currents suggest a much more limited expression pattern. As such there is considerable uncertainty regarding the expression of $\mathrm{P} 2 \mathrm{X}_{2}$, despite its established role in cellular signaling, particularly in the peripheral nervous system (Rong et al., 2003; Cockayne et al., 2005; Finger et al., 2005; McCord et al., 2010; Huang et al., 2011; Weigand et al., 2012).

Here, we used genetic targeting of the endogenous $\mathrm{P} 2 \mathrm{X}_{2}$ locus to generate a knock-in reporter mouse that

This work was supported by the National Institutes of Health's Office of Director SPARC Commonfund Program Grant OT2OD023854, the National Institute for Neurological Disorders and Stroke Grant U01NS113868, and National Institute of Diabetes and Digestive and Kidney Diseases Grants R01DK110366 and U01DK116311.

Correspondence should be addressed to Thomas E. Taylor-Clark at ttaylorclark@usf.edu.

https://doi.org/10.1523/ENEURO.0203-20.2020

Copyright (c) $2020 \mathrm{Kim}$ et al.

This is an open-access article distributed under the terms of the Creative Commons Attribution 4.0 International license, which permits unrestricted use, distribution and reproduction in any medium provided that the original work is properly attributed. expresses Cre recombinase in $\mathrm{P}_{2} \mathrm{X}_{2}$-expressing cells. After crossing this strain with a cre-sensitive tdTomato reporter mouse strain, we visualized $\mathrm{P}_{2} \mathrm{X}_{2}$ expression in sensory ganglia, the CNS and in peripheral tissues. We found robust reporter expression in nodose vagal neurons but not in jugular vagal neurons, and reporter expression was limited to few neurons in the trigeminal ganglia and dorsal root ganglia (DRG). We confirmed the expression of $\mathrm{P} 2 \mathrm{X}_{2}$ in tdTomato-expressing vagal neurons by assessing $\mathrm{Ca}^{2+}$ influx in response to the $\mathrm{P} 2 \mathrm{X}_{2 / 3}$ agonist $\alpha \beta$ mATP using fura-2 AM. Reporter expression was used to visualize $\mathrm{P} 2 \mathrm{X}_{2}$-expressing terminals in the tongue, carotid body, trachea and esophagus as well as in the nucleus tractus solitarius (nTS) in the dorsal medulla (the location of central terminations of nodose sensory afferents). Elsewhere in the CNS, reporter expression was largely limited to medullary and pontine neurons protecting mossy fibers to the cerebellum, although reporter expression was also noted in a small number of cerebellar Purkinje neurons, cerebral cortical neurons and caudoputamen neurons. Lastly, we observed expression in hair cells and support cells in the organ of Corti in the cochlea. Thus, this reporter mouse demonstrates the specific expression of the purinergic receptor $\mathrm{P}_{2} \mathrm{X}_{2}$ and provides a novel tool to study the structure and function of these particular cells.

\section{Materials and Methods}

\section{Knock-in mouse model development}

The gene for the murine $\mathrm{P}_{2} \mathrm{X}_{2}$ receptor ( $P 2 r \times 2$ gene, NCBI Reference Sequence: NM_153400.4) is located on chromosome 5. Eleven exons have been identified, with the ATG start codon in exon 1 and TGA stop codon in exon 11. In order to develop a knock-in mouse that expresses Cre recombinase dependent on $\mathrm{P} 2 \mathrm{X}_{2}$ expression, the P2X $\mathrm{X}_{2}$ TGA stop codon was replaced with a $2 \mathrm{~A}-\mathrm{Cre}$ cassette (Fig. 1). The targeting vector homology arms were generated by high fidelity Taq PCR using BAC clone RP23-333M22 and RP23-354018 from the C57BL/6J library as template. The targeting vector was assembled with recombination sites and selection markers: neomycin resistance gene $\left(\mathrm{Neo}^{\mathrm{R}}\right)$ flanked by self-deletion anchor (SDA) sites for positive selection and diphtheria toxin A fragment gene (DTA) for negative selection. Correct targeting vector synthesis was confirmed by appropriate digestion by restriction enzymes. The linearized vector was subsequently delivered to C57BL/6 ES cells via electroporation, followed by drug selection, PCR screening, and Southern blotting confirmation. After gaining 94 neomycin-resistant clones, 18 potentially targeted clones were confirmed, five of which were expanded for Southern blotting. After confirming correctly targeted ES clones via Southern blotting, clones were selected for blastocyst microinjection, followed by founder production. Founders were confirmed as germline-transmitted via crossbreeding with wild type. All aspects of knock-in mouse development were performed by Cyagen US Inc (California). Founders were mated to produce heterozygous and homozygous mice (P2rx2 ${ }^{\text {tm1.1( }(\mathrm{cre}) \text { Ttc }}$, MGl:2665170) in expected 
A Wildtype allele

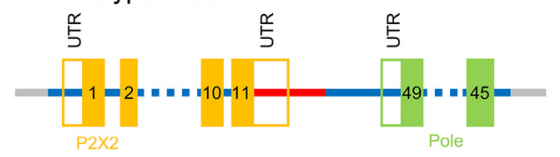

Targeting vector
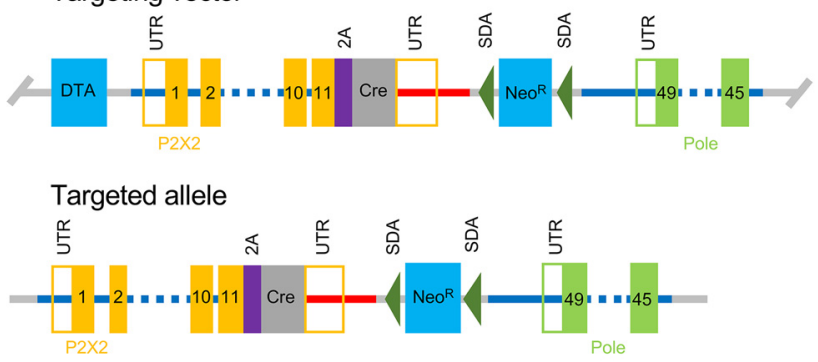

Constitutive knockin allele

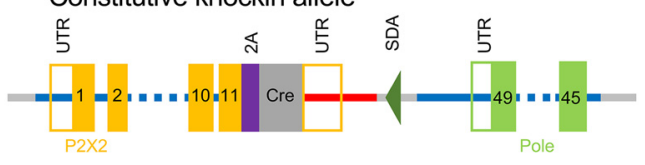

\section{B}

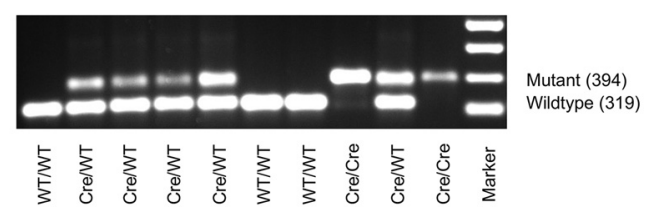

Figure 1. Development of the knock-in $\mathrm{P} 2 \mathrm{X}_{2}$ Cre mouse. $\boldsymbol{A}$, Targeting strategy for the replacement of the $\mathrm{P} 2 \mathrm{X}_{2}$ TGA stop codon with a $2 \mathrm{~A}$-Cre cassette (2A self-cleaving peptide in purple, Cre in dark gray). Homology arms (blue and red lines) were generated for the $\mathrm{P}_{2} \mathrm{X}_{2}$ gene [exons, $5^{\prime}$ and $3^{\prime}$ untranslated regions (UTRs) in orange] and the latter portion of the neighboring Pole gene (exons, and $3^{\prime}$ UTR in green). Homology arms of targeting vector include a neomycin resistance gene $\left(\mathrm{Neo}^{\mathrm{R}}\right)$ flanked by SDA sites for positive selection. A Diphtheria toxin A fragment gene (DTA) was placed in a non-homologous region of targeting vector as a negative selection for non-homologous recombination. $\boldsymbol{B}, \mathrm{PCR}$ of $\mathrm{P} 2 \mathrm{X}_{2}$ gene in offspring from a pairing of heterozygous $\mathrm{P} 2 \mathrm{X}_{2}{ }^{\text {Cre }}$ mice. As expected, offspring have a mendelian distribution of mutant (i.e., $\mathrm{P}_{2} \mathrm{X}_{2}$ Cre , at $394 \mathrm{bp}$ ) and wild-type (at $319 \mathrm{bp}$ ) alleles.

Mendelian proportions. These mice express $\mathrm{P} 2 \mathrm{X}_{2}-2 \mathrm{~A}-$ Cre from the endogenous $\mathrm{P}_{2} \mathrm{X}_{2}$ gene. Upon translation, the $2 \mathrm{~A}$ peptide self-cleaves (Furler et al., 2001) to release $\mathrm{P}_{2} \mathrm{X}_{2}$ and Cre as separate peptides. P2rx2tm1.1(cre)Ttc mice develop normally and were observed to have no apparent phenotype. Homozygous P2rx $2^{\text {tm1.1(cre)Ttc }}$ were crossed with the ROSA26-loxP-STOP-loxP-tdTomato mice (B6.Cg-Gt(ROSA)26Sortm9(CAG-tdTomato)Hze/J, $\# 007909$, The Jackson Laboratory) to produce $P_{2} X_{2}{ }^{C r e /+}$ / ROSA26-tdTomato ${ }^{\mathrm{fl} /+}$ (P2X $\mathrm{P}_{2}$-tdTomato mice), with cellspecific expression of tdTomato via Cre recombination. Specific alleles were confirmed by genotyping per developers' instructions. Both male and female mice (six to eight weeks old) were used for experiments. Offspring were weaned at 21 postnatal days and up to four littermates were housed per cage under normal condition $\left(20^{\circ}\right.$ $\mathrm{C}$, a 12/12 $\mathrm{h}$ light/dark cycle). Mice were provided with standard rodent chow and water ad libitum. All procedures were in accordance with the animal protocol approved by the Institutional Animal Care and Use Committee.

\section{Tissue collection and immunofluorescence}

Mice were euthanized by $\mathrm{CO}_{2}$ inhalation and transcardially perfused with ice-cold PBS followed by perfusion fixation with ice-cold $3.7 \%$ formaldehyde (FA). Vagal ganglia, petrosal ganglia, trigeminal ganglia, thoracic DRG $\left(T_{1}-T_{5}\right)$, and carotid body were dissected out and postfixed for $1 \mathrm{~h}$ in $3.7 \% \mathrm{FA}$ at $4^{\circ} \mathrm{C}$. Medulla, spinal cord, and tongue were collected and postfixed for $4 \mathrm{~h}$ in $3.7 \% \mathrm{FA}$ at $4^{\circ} \mathrm{C}$. Brains were collected and postfixed overnight in $3.7 \% \mathrm{FA}$ at $4^{\circ} \mathrm{C}$. For the cochlea, the temporal bones were collected and postfixed in $4 \%$ PFA overnight at $4^{\circ} \mathrm{C}$. The temporal bones were washed three times in PBS for $10 \mathrm{~min}$ and transferred to $10 \%$ EDTA (dissolved in $\mathrm{H}_{2} \mathrm{O}$, $\mathrm{pH}$ 7.2) solution for overnight decalcification at $4^{\circ} \mathrm{C}$. Tissue firmness was checked by pressing tissue with forceps to ensure adequate decalcification.

All tissues were washed in PBS to remove residual FA and transferred to $20 \%$ sucrose solution for cryoprotection. Tissue were mounted in optimal cutting temperature (OCT) compound and snap frozen in dry-ice before cryosectioning: sensory ganglia $(20 \mu \mathrm{m})$, carotid bodies $(20 \mu \mathrm{m})$, tongue $(40 \mu \mathrm{m})$, cochlea $(40 \mu \mathrm{m})$, spinal cord $(20 \mu \mathrm{m})$, medulla (40 $\mu \mathrm{m}$ for coronal, $80 \mu \mathrm{m}$ for sagittal), and brain $(80 \mu \mathrm{m})$. All slices were collected onto Superfroast plus slides. Slides were then air-dried at room temperature in the dark overnight. For immunofluorescence, sectioned tissue was permeabilized with $0.3 \%$ Triton X-100 in PBS (PBSTx) for 15 min followed by blocking with $1 \%$ bovine serum albumin (BSA) $/ 10 \%$ donkey serum (DS)/0.3\% PBSTx. Sectioned tissue was incubated with primary antibodies diluted in blocking buffer overnight at $4^{\circ} \mathrm{C}$. Sensory ganglia slices were stained for immunoreactivity to TRPV1 (goat, 1:150, sc12498 , Santa Cruz), the neurotrophin receptors tyrosine receptor kinase A (TRKA; rabbit, 1:300, 06-574, Millipore) or pgp9.5 (rabbit, 1:300, AB5925, Millipore). Carotid body slices were immunostained against tyrosine hydroxylase $(\mathrm{TH}$; rabbit, 1:300, AB112, Abcam). Sequentially sectioned medulla slices were stained against TRPV1 (guinea pig, 1:150, GP14100, Neuromics). After washing with 0.2\% Tween 20 in PBS (PBST) three times for $10 \mathrm{~min}$, tissue was incubated with appropriate secondary antibodies [chicken anti-goat 647 (1:300, A212345, Invitrogen), donkey anti-rabbit 488 (1:300, A21206, Invitrogen), and donkey anti-guinea pig 647 (1:300, AP193SA6, Millipore)] in 1\% BSA $5 \%$ DS in $0.2 \%$ PBST for $1 \mathrm{~h}$. Tissue was washed with $0.2 \%$ PBST three times for 10 min and rinsed briefly with $\mathrm{H}_{2} \mathrm{O}$. In some cases, sectioned tissue was counterstained with either green or blue fluorescent Nissl staining (1:600, NeuroTrace 500/525 or 435/455, Fluorescent NissI Stain, Invitrogen). Slides were air dried and mounted with DPX mounting medium (Sigma) or mounted with VECTASHIELD Antifade Medium with DAPI (Vector laboratories).

\section{Wholemount immunostaining of trachea and esophagus}

The mouse trachea was split lengthwise by making a single cut through the midline. The esophagus was cut 
around the stomach and then split lengthwise. The mucosal and muscle layers of the esophagus were separated carefully by small sharp dissection scissors. We stained the trachea by first permeabilizing with $1 \%$ Tween 20 (Sigma-Aldrich) in filtered $1 \times$ PBS for $6 \mathrm{~h}$ at room temperature, then washed three times for 20 min in filtered $1 \times$ PBS using rotator. Permeabilized tracheal tissues were incubated with rabbit anti-RFP primary antibody (1:200, 600-401-379, Rockland antibodies) in PBS with 1\% BSA for $48 \mathrm{~h}$ at $4^{\circ} \mathrm{C}$ (repositioned five to six times during incubation), washed in filtered $1 \times$ PBS ten times using rotator at $4^{\circ} \mathrm{C}$, incubated with secondary antibody goat-anti-rabbit Alexa Fluor 568 (Invitrogen) with dilution 1:100 in filtered $1 \times$ PBS for $5 \mathrm{~h}$ at room temperature. Trachea were then washed in filtered $1 \times$ PBS (three times, rotator, $4^{\circ} \mathrm{C}$ ), incubated in anti-fade glycerol $(\mathrm{pH} 8.6,10 \times$ Tris-buffered saline mixed with glycerol) for $24 \mathrm{~h}$ at room temperature and stored in anti-fade glycerol at $4^{\circ} \mathrm{C}$. The esophageal tissues went through the same treatment as the trachea, but the main difference was that we amplified the tdTomato signal by using a streptavidin-biotin protocol. In short, after the primary antibody step, the tissues were washed in $1 \times$ PBS and then incubated with goat biotin$X X$ conjugate anti-rabbit $\lg G(\mathrm{H}+\mathrm{L})$ secondary antibody (1:100, B2770, Invitrogen) in 1\% PBS/BSA overnight at room temperature (repositioned one to two times during incubation), washed in filtered $1 \times$ PBS 10 times using rotator at $4{ }^{\circ} \mathrm{C}$, and incubated with streptavidin conjugated with fluorescent dye Alexa Fluor 568 (Invitrogen) with dilution 1:100 in filtered $1 \times$ PBS for $5 \mathrm{~h}$ at room temperature. All stained tissues were then positioned muscular or mucosal side up on a glass slide and covered with coverslip $24 \times 50 \mathrm{~mm}$. In the first stained preparation, we found numerous randomly distributed oval solid artifacts. Optimization of staining procedure revealed that these artifacts attributable to the use of $1 \%$ goat blocking serum. In control experiments, omitting goat serum eliminated these artifacts, while including goat serum reproduced them. Therefore, in all subsequent staining, goat serum was omitted.

\section{Visualization of reporter expression in sectioned and wholemount tissue}

Images were taken with either Olympus FV1200 laser scanning confocal microscope or Andor Dragonfly spinning disk confocal microscope using Fusion software, and projection images were processed with Imaris software. In all cases the identification of anatomic structures and subnuclei were based on the mouse brain map (Paxinos and Franklin, 2012). $Z$ stack images $(10 \times$ and $20 \times$ ) of the mouse esophagus and trachea (wholemount) were taken using Andor Dragonfly spinning disk microscope. Nerve terminals in the epithelial and subepithelial layers of the trachea were traced using Neurolucida 360 software (MBF Biosciences), as previously described (Dickstein et al., 2016): the 20x images were spaced at $0.6 \mu \mathrm{m}$. First, automatic nerve terminal detection (Rayburst crawl) was used, seeds were validated, then manual tracing was used to complete the tracing.

\section{Vagal ganglia dissociation}

Male 6- to 12-week-old P2X $\mathrm{X}_{2}$-tdTomato mice were euthanized by $\mathrm{CO}_{2}$ asphyxiation followed by exsanguination. As previously described (Stanford and Taylor-Clark, 2018), vagal ganglia were isolated in $\mathrm{Ca}^{2+}$ free, $\mathrm{Mg}^{2+}$ free HBSS, then incubated in HBSS containing collagenase $(2 \mathrm{mg} / \mathrm{ml})$ and dispase $(2 \mathrm{mg} / \mathrm{ml})$, then mechanically dissociated with fire-polished pipettes. Individual neurons were washed with $\mathrm{L}-15$ media supplemented with $10 \%$ fetal bovine serum, $100 \mathrm{U} / \mathrm{ml}$ penicillin, and $100 \mu \mathrm{g} / \mathrm{ml}$ streptomycin, then plated onto poly-D-lysine and laminincoated coverslips. Neurons were incubated at $37^{\circ} \mathrm{C}$ in antibiotic-free L-15 media supplemented with $10 \%$ fetal bovine serum and used within $24 \mathrm{~h}$.

\section{Live neuron $\mathrm{Ca}^{2+}$ imaging and analysis}

Neurons were incubated with $4 \mu \mathrm{M}$ fura-2 AM for 30$60 \mathrm{~min}$ at $37^{\circ} \mathrm{C}$. Coverslips were loaded into a chamber on an inverted microscope and perfused with heated (33-34 C) HEPES buffer $(154 \mathrm{~mm} \mathrm{NaCl}, 1.2 \mathrm{~mm} \mathrm{KCl}, 1.2 \mathrm{~mm}$ $\mathrm{MgCl}_{2}, 2.5 \mathrm{~mm} \mathrm{CaCl}_{2}$, and $5.6 \mathrm{~mm} \mathrm{D}$-glucose). Slides equilibrated for $10 \mathrm{~min}$ before the start of the experiment and an image was taken to visualize tdTomato fluorescence (535-nm excitation, 610-nm emission). Changes in $\left[\mathrm{Ca}^{2+}\right]_{\mathrm{i}}$ was monitored using sequential excitation at 340 and $380 \mathrm{~nm}$ (510-nm emission) with images taken every $6 \mathrm{~s}$ using a CoolSnap HQ2 camera (Photometrics) and evaluated ratiometrically using the $340 / 380$ ratio. All drugs were diluted in HEPES buffer. $\alpha \beta$ mATP $(10 \mu \mathrm{M})$ was used to determine the functional expression of $\mathrm{P} 2 \mathrm{X}_{2 / 3}$ channels (Taylor-Clark et al., 2015). The $\mathrm{EC}_{50}$ for $\alpha \beta \mathrm{mATP}$-evoked activation of $\mathrm{P}_{2} \mathrm{X}_{2 / 3}$ channels is $\sim 3-9 \mu \mathrm{M}$ (Khakh et al., 2001; Liu et al., 2001). Capsaicin (1 $\mu \mathrm{M}$ ) was used to determine the functional expression of the nociceptive ion channel TRPV1 (Taylor-Clark et al., 2015). Neurons were further characterized by response to $\mathrm{KCl}(75 \mathrm{~mm})$ before ionomycin $(5 \mu \mathrm{M})$, which evoked a maximal $\mathrm{Ca}^{2+}$ response. Image analysis was performed by using Nikon Elements (Nikon) by drawing individual regions of interest (ROls) that around the intracellular region for each cell and tracked over time. ROls with an unstable, high, or noisy baseline were eliminated from analysis. Neurons which failed to exhibit an increase in $\left[\mathrm{Ca}^{2+}\right]_{\mathrm{i}}$ to either $\alpha \beta \mathrm{mATP}$, capsaicin or $\mathrm{KCl}$ challenges $(>30 \%$ the ionomycin maximal response) were eliminated. Relative changes in $\left[\mathrm{Ca}^{2+}\right]_{\mathrm{i}}$ were determined ratiometrically using fura-2 fluorescence: $340 / 380$ ratio (R). This negates the impact of cell to cell variations in fura- 2 AM loading. Data are presented as changes in the $340 / 380$ ratio $\left(\Delta R=R_{1}-R_{0}\right)$, where $R 0$ is the average $340 / 380$ ratio before mATP treatment. As before (Stanford and Taylor-Clark, 2018; Stanford et al., 2019), an individual neuron was considered to be sensitive to a given agent if $R_{\text {agent }}>\left(R_{b l}+\right.$ $\left.2 * \mathrm{SD}_{\mathrm{bl}}\right)+0.075$, where $\mathrm{R}_{\text {agent }}$ is the average $340 / 380$ ratio during treatment, $R_{b l}$ is the average $340 / 380$ ratio before treatment, and $S D_{b l}$ is the $S D$ of $R_{b l}$. Neurons were grouped by tdTomato expression and sensitivity to $\alpha \beta \mathrm{mATP}$ and capsaicin. Data and statistical analyses were performed using Microsoft Excel and GraphPad Prism 7. Mean $\mathrm{Ca}^{2+}$ responses were compared using 
A
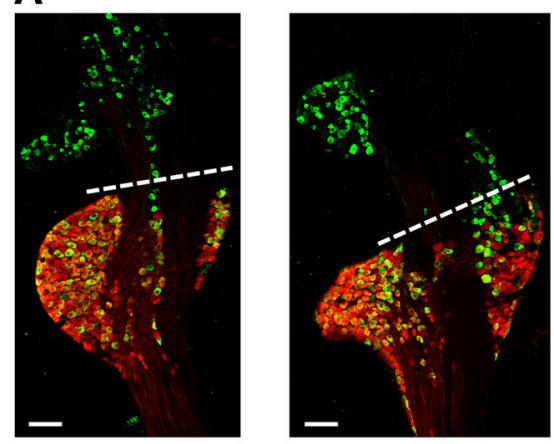

tdTomato $\alpha$-TRPV1
B

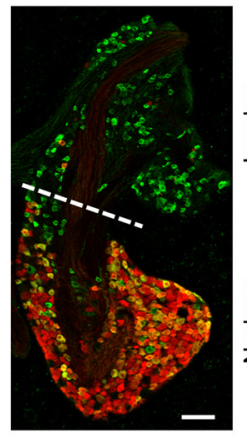

$-$

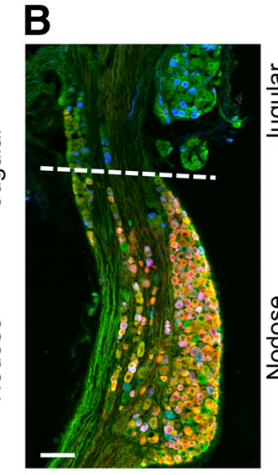

tdTomato $\alpha$-pgp9.5 $\alpha$-TRPV1
C

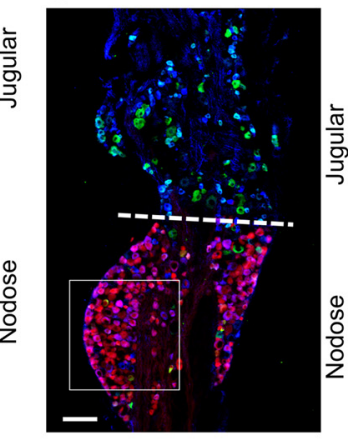

tdTomato $\alpha$-TRKA $\alpha$-TRPV1

D

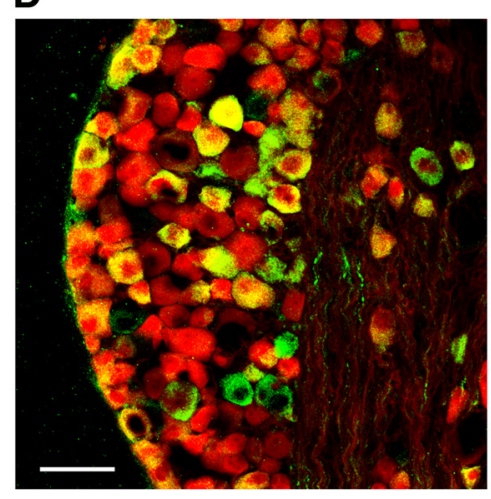

tdTomato $\alpha$-TRPV1

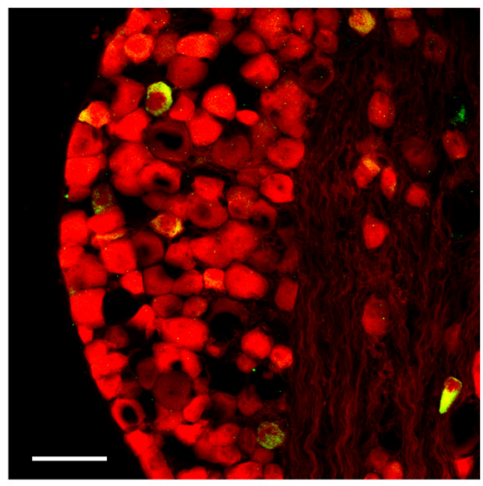

tdTomato $\alpha$-TRKA

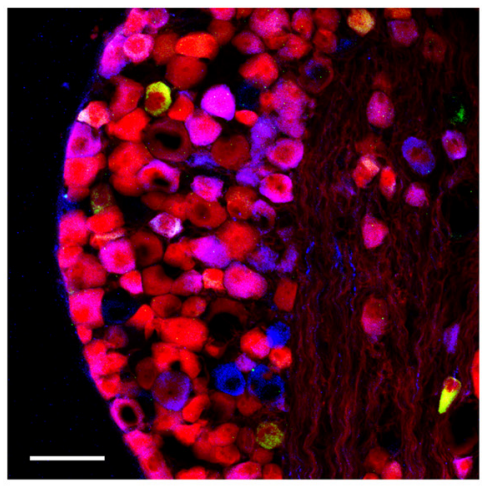

tdTomato $\alpha$-TRKA $\alpha$-TRPV1

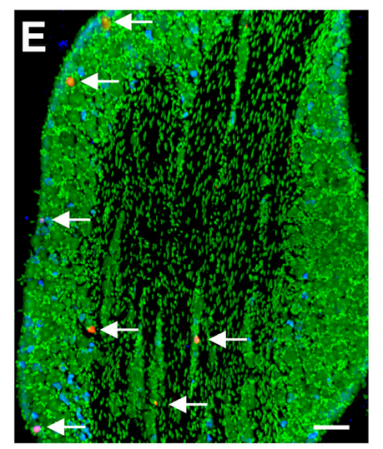

tdTomato Neurotrace $\alpha$-TRPV1

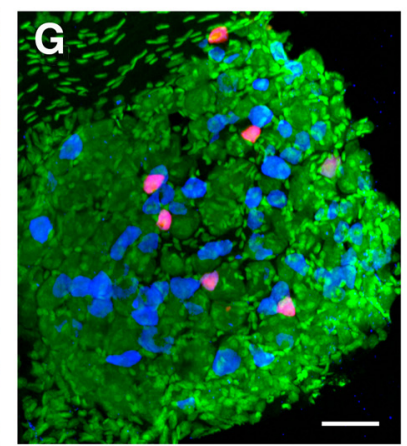

$\longrightarrow$

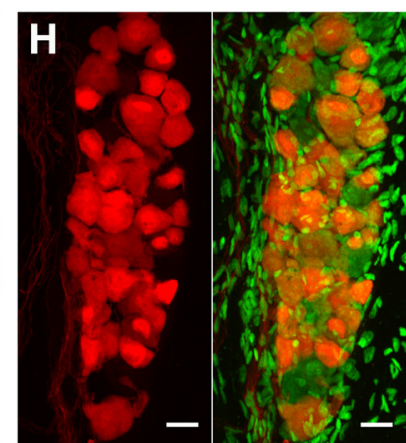

tdTomato + Neurotrace

Figure 2. tdTomato expression in $\mathrm{P} 2 \mathrm{X}_{2}$-tdTomato mice is restricted to subsets of sensory afferents. $\boldsymbol{A}-\boldsymbol{C}$, tdTomato (red) expression in vagal ganglia, with the demarcation of the nodose and jugular regions delineated by dotted line. A, Counterstained for TRPV1 (green) expression. B, Counterstained for TRPV1 (blue) and pgp9.5 (green) expression. C, Counterstained for TRPV1 (blue) and TRKA (green) expression. $\boldsymbol{D}$, tdTomato (red) expression in nodose neurons identified in $\boldsymbol{C}$. Left, Counterstained for TRPV1 (green) expression. Middle, Counterstained for TRKA (green) expression. Right, Counterstained for TRPV1 (blue) and TRKA (green) expression. $\boldsymbol{E}-\mathbf{G}$, tdTomato (red) expression counterstained for TRPV1 expression (blue) and with NeuroTrace (green). E, Maxillary/ophthalmic region of the trigeminal ganglia. tdTomato+ neurons identified by white arrows. $\boldsymbol{F}$, Mandibular region of the trigeminal ganglia. $\boldsymbol{G}$, DRG. $\boldsymbol{H}$, Petrosal ganglia, counterstained with NeuroTrace (green). Scale bars: $100 \mu \mathrm{m}(\boldsymbol{A}-\boldsymbol{C}, \boldsymbol{E}), 50 \mu \mathrm{m}(\boldsymbol{D}, \boldsymbol{F}, \boldsymbol{G})$, and $20 \mu \mathrm{m}(\boldsymbol{H})$. Data are derived from five vagal ganglia, five trigeminal ganglia, four DRG, and four petrosal ganglia.

Student's $t$ test; $p=0.05$ was taken as the threshold for significance.

\section{Results}

To investigate the expression of $\mathrm{P}_{2} \mathrm{X}_{2}$, we generated a knock-in $\mathrm{P}_{2} \mathrm{X}_{2}{ }^{\text {Cre }}$ mouse (Fig. 1), which was crossed with the cre-sensitive ROSA26-loxP-STOP-loxP-tdTomato

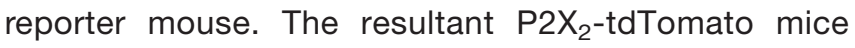

express the red fluorescent tdTomato in $\mathrm{P} 2 \mathrm{X}_{2}$-expressing cells.

Cryostat sections of the vagal ganglia from four $\mathrm{P}_{2} \mathrm{X}_{2}-$ tdTomato mice showed robust and selective expression of tdTomato in nodose vagal sensory neurons, whereas there was little tdTomato expression in jugular vagal sensory neurons (1045 vs 16 tdTomato+ neurons, respectively; Fig. 2A). Vagal ganglia from two of these $\mathrm{P}_{2} \mathrm{X}_{2}-$ 
A

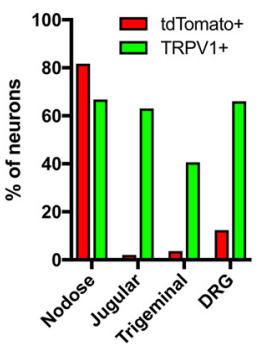

B

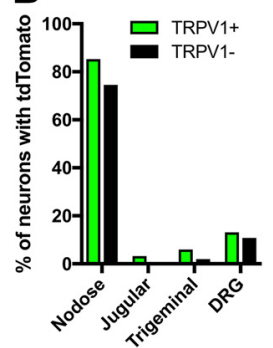

Figure 3. Quantification of tdTomato and TRPV1 expression in vagal, trigeminal, and DRG afferents. $\boldsymbol{A}$, The \% of neurotrace+ neurons that express tdTomato and TRPV1. $\boldsymbol{B}$, The \% of TRPV1+ neurons and TRPV1- neurons that also express tdTomato. Data are derived from two vagal ganglia, five trigeminal ganglia, and three thoracic DRG.

tdTomato mice were assessed for NeuroTrace (Nissl) staining (data not shown) to calculate the percentage of neurons that expressed tdTomato. More than $80 \%$ of nodose neurons were tdTomato+, compared with just $2 \%$ of jugular neurons (Fig. $3 A$ ). This is consistent with data from vagal ganglia from $\mathrm{P}_{2} \mathrm{X}_{2}$-tdTomato stained for the neuronal marker pgp9.5, which again showed that few nodose neurons failed to express tdTomato (Fig. 2B). tdTomato expression in nodose neurons was noted in $>75 \%$ of both TRPV1+ and TRPV1- populations (Figs. $2 A-D, 3 B$ ). Very few tdTomato + neurons also expressed TRKA, which was widely expressed in jugular neurons (Fig. 2C,D). We then investigated tdTomato expression in the trigeminal and thoracic DRG of $\mathrm{P} 2 \mathrm{X}_{2}$-tdTomato mice. In sections counterstained with NeuroTrace, we found only $3.6 \%$ of trigeminal neurons were tdTomato + , and these were equally distributed between the maxillary/ophthalmic and mandibular regions (Figs. 2E,F, 3A). The rare tdTomato+ trigeminal neurons were mostly TRPV1+ (Figs. 2E,F, 3B). Few DRG neurons (12.3\%) expressed tdTomato (Figs. 2G, 3A), although these were equally split between TRPV1+ and TRPV1- populations (Figs. 2G, $3 B$ ). Lastly, we found extensive tdTomato expression within the petrosal ganglia, with $75 \%$ of petrosal neurons from four ganglia expressing the marker (Fig. 2H).
To link tdTomato expression to $\mathrm{P} 2 \mathrm{X}_{2}$ expression in the $\mathrm{P} 2 \mathrm{X}_{2}$-tdTomato mouse, we investigated the sensitivity of vagal sensory neurons to the $\mathrm{P}_{2 / 3}$ agonist $\alpha \beta \mathrm{mATP}$. Previous studies indicate that virtually all nodose and jugular neurons express $\mathrm{P} 2 \mathrm{X}_{3}$, but $\mathrm{P} 2 \mathrm{X}_{2}$ is only expressed in nodose neurons (Cockayne et al., 2005; Kwong et al., 2008; Nassenstein et al., 2010; Surdenikova et al., 2012; Trancikova et al., 2018). $\alpha \beta$ mATP only causes significant vagal neuron activation in neurons that express both $\mathrm{P} 2 \mathrm{X}_{2}$ and P2X ${ }_{3}$ (Lewis et al., 1995; Dunn et al., 2001; Khakh et al., 2001). Here, we assessed $\mathrm{Ca}^{2+}$ fluxes in dissociated P2X $\mathrm{X}_{2}$-tdTomato vagal neurons in response to $\alpha \beta \mathrm{mATP}$ (10 $\mu \mathrm{M})$ and the TRPV1 agonist capsaicin (1 $\mu \mathrm{M})$ in 478 tdTomato + and 200 tdTomato- neurons (Fig. 4). The mean response to $\alpha \beta \mathrm{mATP}$ was significantly greater in tdTomato + neurons compared with tdTomato- neurons $(0.29 \pm 0.01$ vs $0.06 \pm 0.01, p<0.05)$. Out of the 478 tdTomato + neurons, 399 neurons responded to $\alpha \beta$ mATP (83.4\%; Fig. $4 C$ ). Only 39 of the 200 tdTomato- neurons (19.5\%) responded to $\alpha \beta$ mATP (Fig. $4 C$ ). The mean $\alpha \beta$ mATP response of $\alpha \beta$ mATP-sensitive neurons was greater in tdTomato + neurons than tdTomato- neurons $(0.35 \pm 0.01$ vs $0.22 \pm 0.04$, $p<0.05$ ). There was no difference in mean capsaicin response between tdTomato + and tdTomato- neurons ( 0.35 \pm 0.02 vs $0.39 \pm 0.04, p>0.05)$. However, there were more capsaicin-sensitive neurons in the tdTomato+ population (261 out of $478,54.6 \%$ ) than in the tdTomato- population (72 out of $200,36.0 \%$ ). As such, the mean capsaicin response in capsaicin-sensitive neurons was significantly smaller in tdTomato + neurons compared with tdTomato- neurons $(0.66 \pm 0.03$ vs $1.08 \pm 0.09, p<0.05)$. Overall, the data indicate that tdTomato expression in vagal neurons of $\mathrm{P}_{2} \mathrm{X}_{2}-$ tdTomato mice is a selective marker of $\alpha \beta \mathrm{mATP}$ sensitivity.

Sensory neurons in the vagal, petrosal and geniculate ganglia project central terminals via the tractus solitarius into the nTS in the brainstem medulla. In sections of the medulla of $\mathrm{P} 2 \mathrm{X}_{2}$-tdTomato mice, we found robust tdTomato expression in fibers within the tractus solitarius and the nTS, in particular in medial and dorsal subnuclei such as the commissural subnucleus (SolC), gelatinous subnucleus (SolG), dorsal lateral subnucleus (SolDL), medial subnucleus (SolM), intermediate subnucleus (SollM), and central subnucleus (SolCe; Fig. 5A,B). We also found
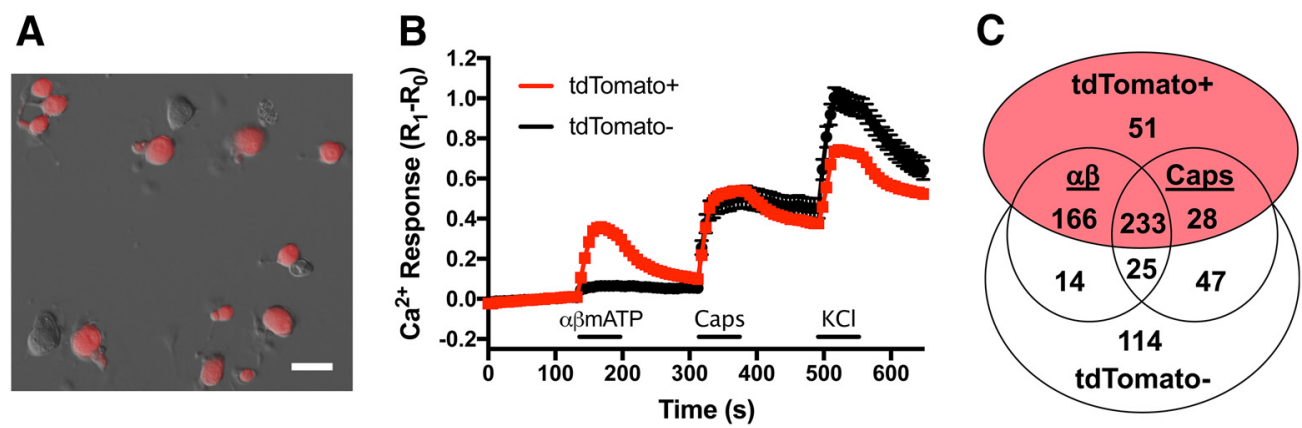

Figure 4. Responsivity to $\alpha \beta$ mATP correlates with reporter expression in vagal neurons from $\mathrm{P}_{2} \mathrm{X}_{2}$-tdTomato mice. $\boldsymbol{A}$, Brightfield image of dissociated vagal neurons overlaid with tdTomato (red) expression. Scale bar: $40 \mu \mathrm{m}$. $\boldsymbol{B}, \mathrm{Mean}^{ \pm} \mathrm{SEM}\left[\mathrm{Ca}^{2+}\right]_{\mathrm{i}}$ responses of tdTomato $+($ red, $n=478$ ) and tdTomato- (black, $n=200)$ vagal neurons to $\alpha \beta \mathrm{mATP}(10 \mu \mathrm{M})$, capsaicin $(\mathrm{Caps}, 1 \mu \mathrm{M})$, and $\mathrm{KCl}(75$ $\mathrm{mm})$. $\boldsymbol{C}$, Euler diagram denoting the number of vagal neurons in each specific subset as determined by tdTomato expression and responsivity to $\alpha \beta$ mATP and capsaicin. 

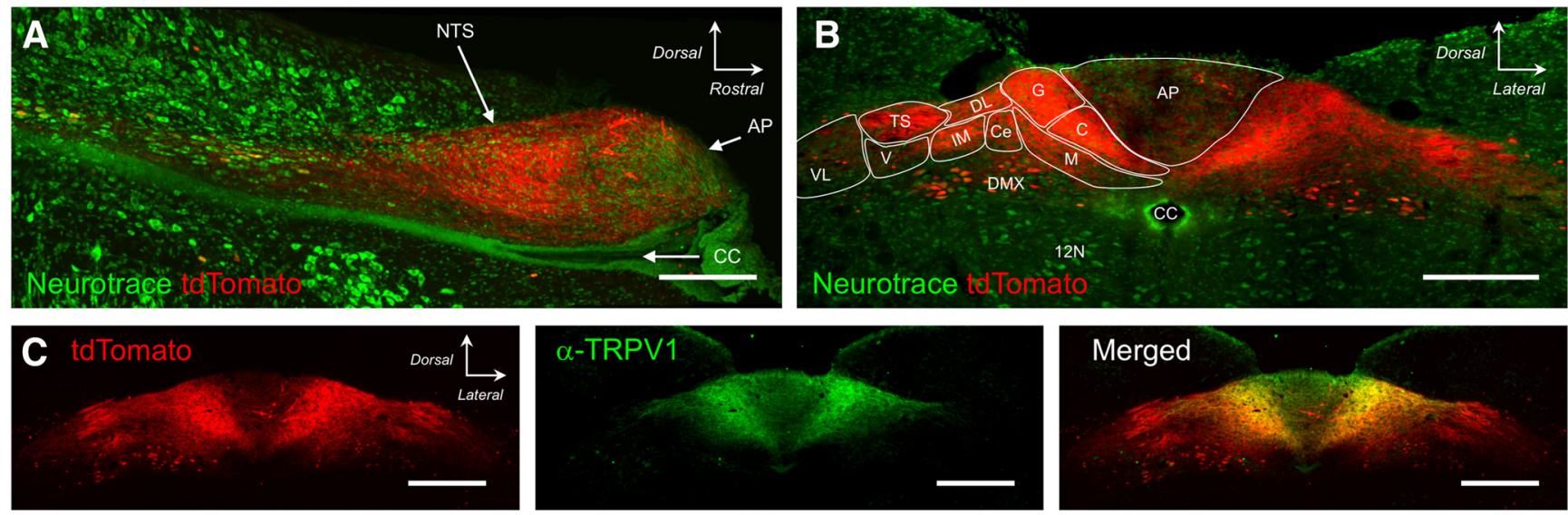

D tdTomato expression
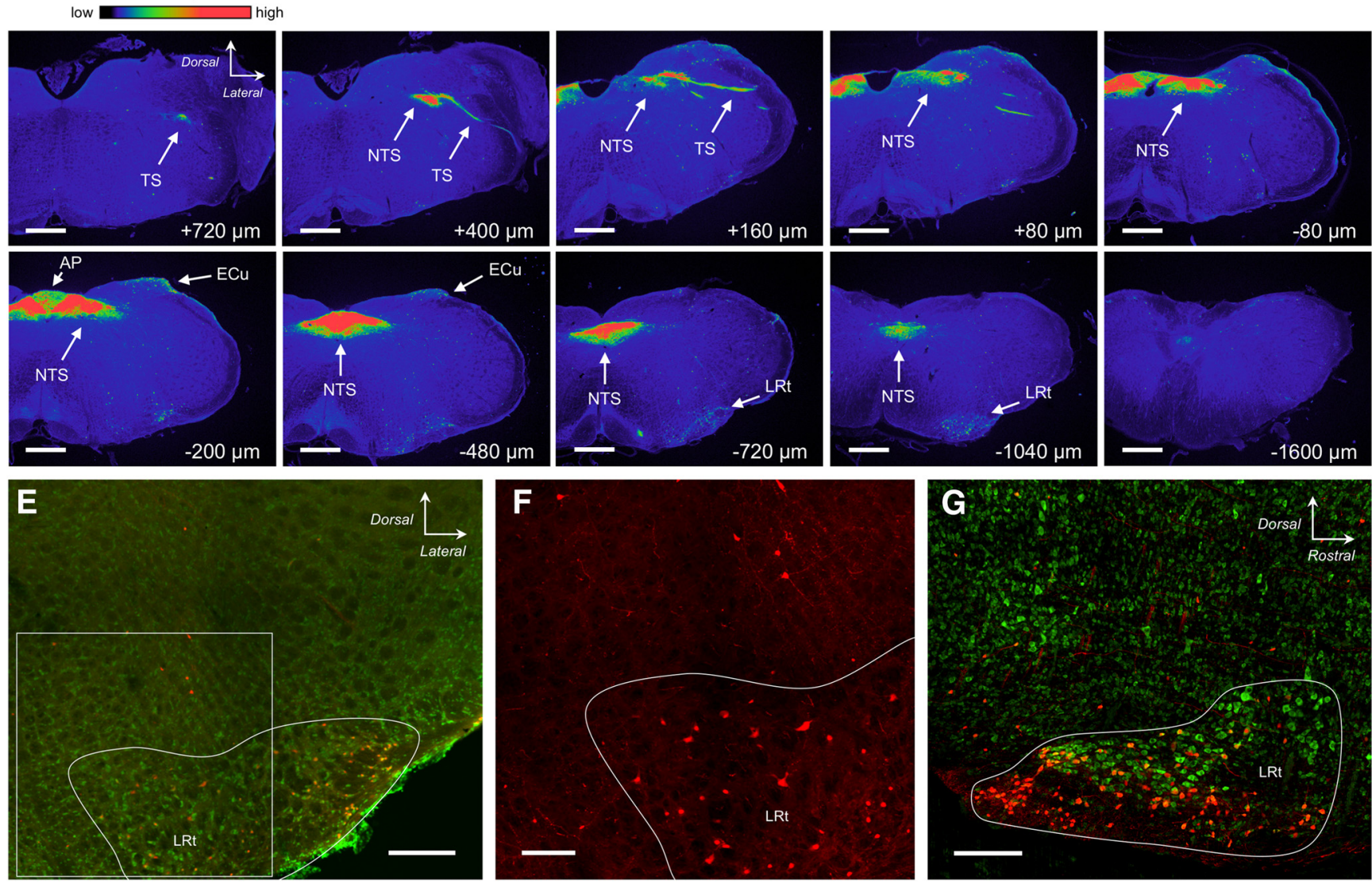

Figure 5. tdTomato expression in the medulla of $\mathrm{P} 2 \mathrm{X}_{2}$-tdTomato mice. $\boldsymbol{A}, \boldsymbol{B}$, tdTomato (red) expression in the dorsal medulla counterstained with NeuroTrace (green). $\boldsymbol{A}$, Sagittal section at midline. $\boldsymbol{B}$, Coronal section at $-300 \mu \mathrm{m}$ (relative to obex). $\boldsymbol{C}$, tdTomato (red) expression counterstained for TRPV1 (green) expression in coronal section at $-390 \mu \mathrm{m}$ (relative to obex). $\boldsymbol{D}$, tdTomato expression in serial coronal sections from rostral to caudal, with labeling for the position relative to obex. The intensity of native tdTomato expression is shown in rainbow pseudocolor. $\boldsymbol{E}-\mathbf{G}$, tdTomato (red) expression in the ventrolateral medulla counterstained with NeuroTrace (green). $\boldsymbol{E}$, Coronal section at $-540 \mu \mathrm{m}$ (relative to obex). $\boldsymbol{F}$, higher magnification of inset in $\boldsymbol{E}$. $\boldsymbol{G}$, Sagittal section at $1.08 \mathrm{~mm}$ lateral to midline. The following structures are identified: area postrema (AP), central canal (CC), external cuneate nucleus $(E C u)$, dorsal motor nucleus of the vagus (DMX), hypoglossal motor nucleus (12N), lateral reticular nucleus (LRt), nucleus tractus solitarius (nTS), SolC (C), SolCe (Ce), SolDL (DL), SolG (G), SolIM (IM), SolM (M), SolV (V), SolVL (VL), and tractus solitarius (TS). Scale bars: $50 \mu \mathrm{m}(\boldsymbol{A}), 300 \mu \mathrm{m}(\boldsymbol{B}, \boldsymbol{C})$, and $500 \mu \mathrm{m}(\boldsymbol{D})$.

some tdTomato+ fibers innervating the ventral subnucleus (SoIV) and ventrolateral subnucleus (SoIVL) and in the area postrema (Fig. 5B). These data are consistent with previous reports that nodose afferents innervate these medulla subnuclei (Kim et al., 2020). Previous studies have also shown that the central projections of TRPV1+ vagal afferents terminate mainly in the medial and dorsal nTS subnuclei and the area postrema (Kim et 

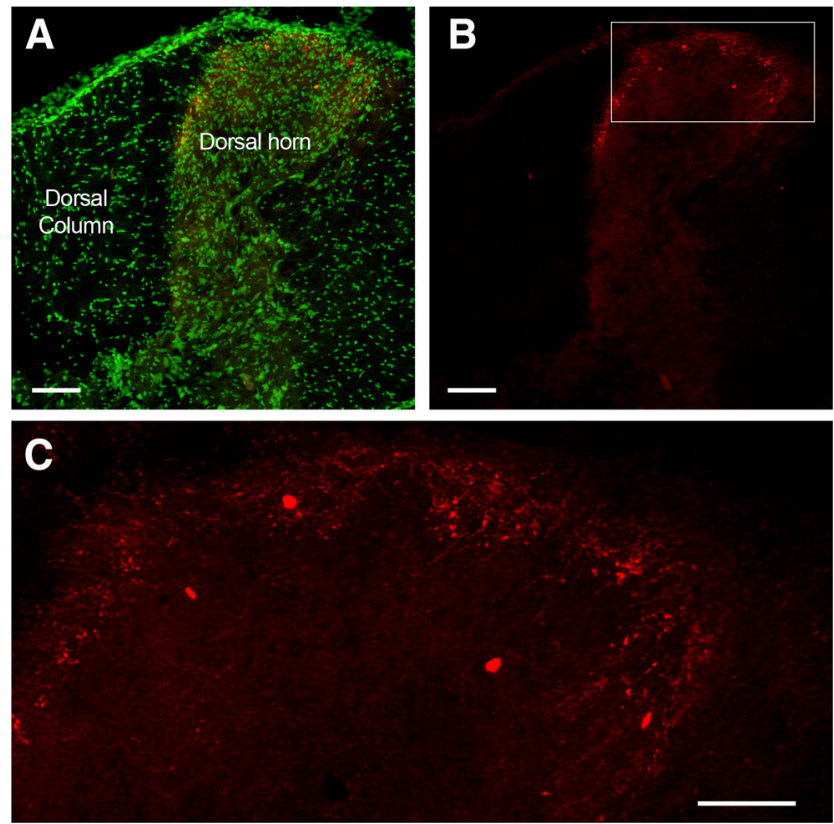

Figure 6. tdTomato expression in the thoracic spinal cord of P2X 2 -tdTomato mice. $\boldsymbol{A}, \boldsymbol{B}$, Coronal sections with tdTomato expression (red), with $(\boldsymbol{A})$ and without $(\boldsymbol{B})$ counterstain by NeuroTrace (green). $\boldsymbol{C}$, Higher magnification of superficial dorsal horn laminae. Scale bars:100 $\mu \mathrm{m}(\boldsymbol{A}, \boldsymbol{B})$ and $50 \mu \mathrm{m}(\boldsymbol{C})$.

al., 2020). Here, we found substantial overlap of TRPV1 immunoreactivity and tdTomato within these areas, but the tdTomato + fibers in lateral and ventral subnuclei did not express TRPV1, thus indicating that P2X 2 TRPV1+ and $P 2 X_{2}+T R P V 1-$ fibers have distinct central terminations (Fig. $5 \mathrm{C}$ ), consistent with electrophysiological recordings of C- and A-fibers (Kubin et al., 1991, 2006). Serial sections indicated that tdTomato + fibers were found along the entire rostral-caudal axis of the nTS (Fig. 5D). There was little tdTomato expression in the medulla other than within the tractus solitarius/nTS/area postrema. In particular, there were only a few sparse tdTomato + terminations within the spinal trigeminal nucleus and the paratrigeminal complex, consistent with rare tdTomato expression in trigeminal afferent neurons. We did note tdTomato expression in minor subsets of neurons within the dorsal motor nucleus of the vagus and the external cuneate (Fig. $5 B, D$ ). Lastly, we found tdTomato + neurons within the lateral reticular nucleus (Fig. 5D-G), which project mossy fibers to the cerebellum. Only a few tdTomato+ neurons were found in the neighboring caudal ventrolateral medulla (Fig. 5D-G). Almost none of the neurons in the rostral ventrolateral medulla expressed tdTomato (Fig. 5D). In the thoracic spinal cord, we observed some tdTomato + fibers within the superficial laminae of the dorsal horn (Fig. 6), consistent with expression of tdTomato in a minor subset of DRG afferents. There was little tdTomato expression in other spinal areas.

We extended our investigation of tdTomato expression to the entire brain of $\mathrm{P} 2 \mathrm{X}_{2}$-tdTomato mice (Fig. 7). As expected, we again found tdTomato expression in the nTS and the lateral reticular nucleus. Interestingly, we also found tdTomato expression in a subset of neurons within the basal pontine nuclei (Fig. $7 B, C$ ), which also project mossy fibers to the cerebellum. Consistent with this, tdTomato + mossy fiber axons within the white matter layer and mossy fiber terminations within the molecular layer were observed throughout each lobule of the cerebellum (Fig. 7D,E). In addition, a minor subset of cerebellar Purkinje cells was tdTomato + (Fig. 7F). No tdTomato+ neurons were observed in the deep cerebellar nuclei. We found very few neurons within the hippocampus expressed tdTomato (Fig. 7G,H), but some tdTomato + fibers were noted within the molecular layer surrounding the dentate gyrus granule cell layer (Fig. $7 /)$. In the cerebral cortex, tdTomato expression was found in a small number of pyramidal neurons, many of which were found in Layers V and VI. In addition, a small number of neurons in the caudoputamen expressed tdTomato.

Next, we investigated tdTomato expression in the carotid body, tongue, trachea, and esophagus, tissues that are thought to be innervated by $\mathrm{P} 2 \mathrm{X}_{2}$-expressing afferents (Rong et al., 2003; Finger et al., 2005; Yu et al., 2005; Kwong et al., 2008; Mazzone and Undem, 2016). In the carotid body, we observed dense terminations of glossopharyngeal tdTomato-expressing fibers innervating $\mathrm{TH}$-expressing glomus type 1 cells (Fig. $8 \mathrm{~A}$, $B)$. We found tdTomato-expressing fibers innervating fungiform, filiform, and circumvallate papillae on the tongue (Fig. 8C-E). Intragemmal tdTomato + terminations were observed in fungiform taste buds, along with the occasional perigemmal tdTomato + terminations. In addition, tdTomato was observed in a subset of cells within the taste buds, which are likely taste cells (Huang et al., 2011). In wholemount preparations of the trachea, we found tdTomato-expressing fibers throughout the entire trachea, although there were far more innervating the dorsal membranous part of the trachea (trachealis muscle regions) than in the anterolateral membranous parts over the cartilaginous rings and ligaments (data not shown). In the membranous portion, tdTomato-expressing fibers were observed from the epithelial layer through to the adventitia (Fig. 8F). Distinct patterns of tdTomato-expressing fibers were noted in each layer. In the adventitia, dense cabling of fibers coursed parallel to the epithelial surface (Fig. 8G). In places, individual thin, punctate-like fibers were observed branching off the larger tdTomato-expressing axons that appeared to travel in bundles (Fig. 8G, inset). Multiple fibers climbed up to the smooth muscle layer, which was densely innervated with a host of parallel fibers following the transversal axis of the trachealis muscle (Fig. $8 H$ ). We found numerous tdTomato-expressing intraepithelial terminations within the membranous part of the trachea. These tended to have similar structures: parental axons proceeding up through the submucosal layer and then undergoing numerous branching in the subepithelial layer resulting in dense highly arborized structures intercalated with the tracheal epithelium (Fig. 8/,J). Nerve tracing software was able to show that each 

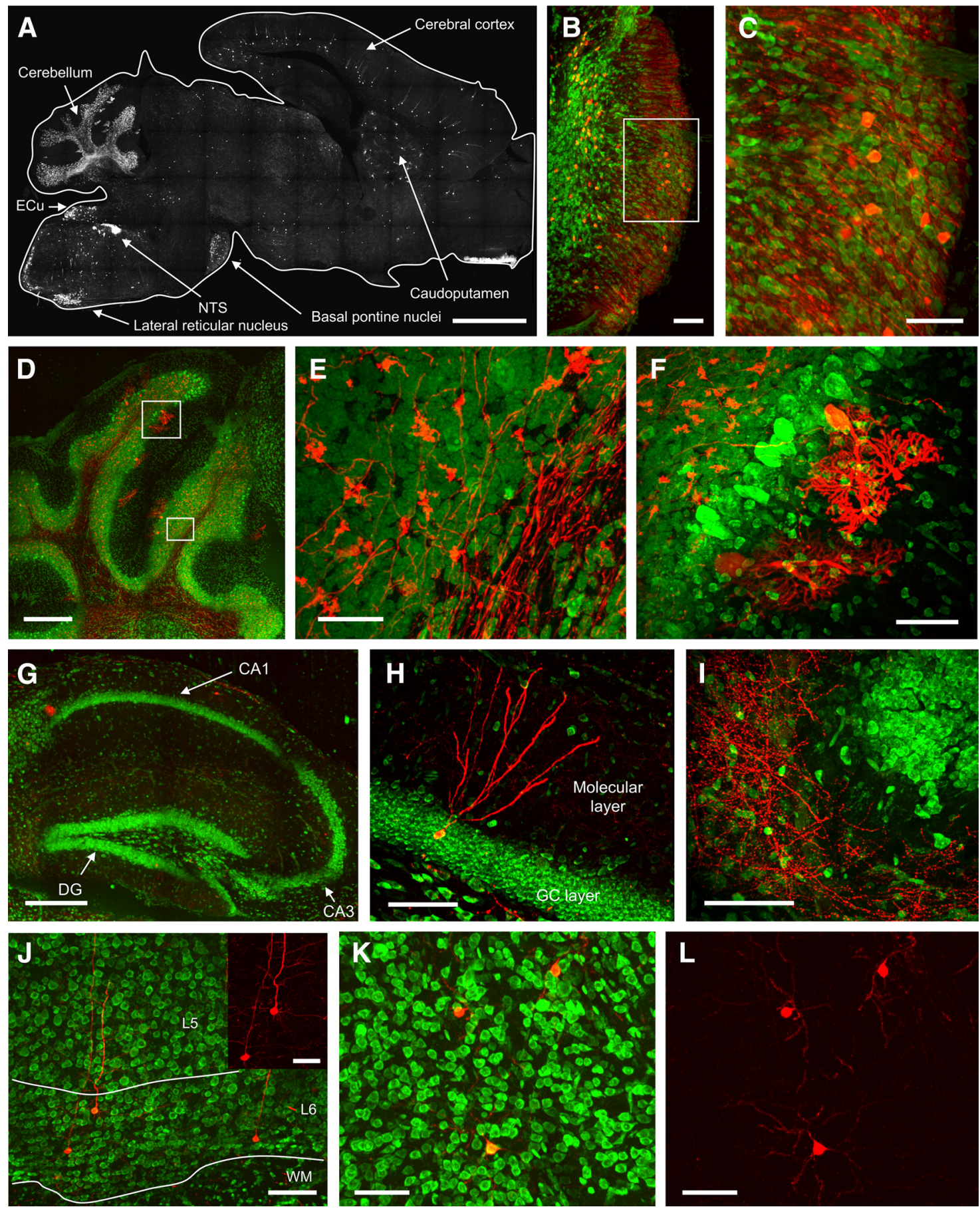

Figure 7. tdTomato expression within the brainstem and brain of $\mathrm{P}_{2} \mathrm{X}_{2}$-tdTomato mice. $\boldsymbol{A}$, tdTomato (white) expression in sagittal section at $1 \mathrm{~mm}$ lateral to the midline. Ecu, external cuneate nucleus; $n T S$, nucleus tractus solitarius. $\boldsymbol{B}-\boldsymbol{L}$, tdTomato (red) expression counterstained with NeuroTrace (green). $\boldsymbol{B}$, Basal pontine nucleus. $\boldsymbol{C}$, High magnification of area identified in $\boldsymbol{B}$. $\boldsymbol{D}$, Cerebellum. $\boldsymbol{E}$, High magnification of area identified in $\boldsymbol{D}$ showing white matter and internal granule layer. $\boldsymbol{F}$, High magnification of area identified in $\boldsymbol{D}$ showing internal granule layer, Purkinje cells and the molecular layer. $\boldsymbol{G}$, Hippocampus. DG, dentate gyrus. $\boldsymbol{H}$, Suprapyramidal blade of the dentate gyrus. GC layer, granular cell layer. I, Apex of the dentate gyrus. $\boldsymbol{J}$, Cerebral cortex; inset shows tdTomato expression without NeuroTrace. L5, layer 5; L6, layer 6; WM, white matter. $\boldsymbol{K}, \boldsymbol{L}$, Caudoputamen with $(\boldsymbol{H})$ and without $(\boldsymbol{I})$ NeuroTrace. Scale bars: $2 \mathrm{~mm}(\boldsymbol{A}), 400 \mu \mathrm{m}(\boldsymbol{D}), 300 \mu \mathrm{m}(\boldsymbol{G}), 100 \mu \mathrm{m}(\boldsymbol{B}, \boldsymbol{J}), 80 \mu \mathrm{m}(\boldsymbol{H}, \boldsymbol{I}), 60 \mu \mathrm{m}(\boldsymbol{C}, \boldsymbol{F}, \boldsymbol{K}, \boldsymbol{L}), 50 \mu \mathrm{m}(\boldsymbol{J}$, inset), and $40 \mu \mathrm{m}(\boldsymbol{E})$.

branch in the arbor was connected to the same parental axon, but we were unable to determine whether the nearby arbors were derived from the same nerve. Lastly, we observed tdTomato-expressing fibers within the mucosal and submucosal layers of the esophagus (Fig. 8K). Often axons ran together through these layers in bundles of more than five axons, but individual punctate-like terminations could also be observed. 

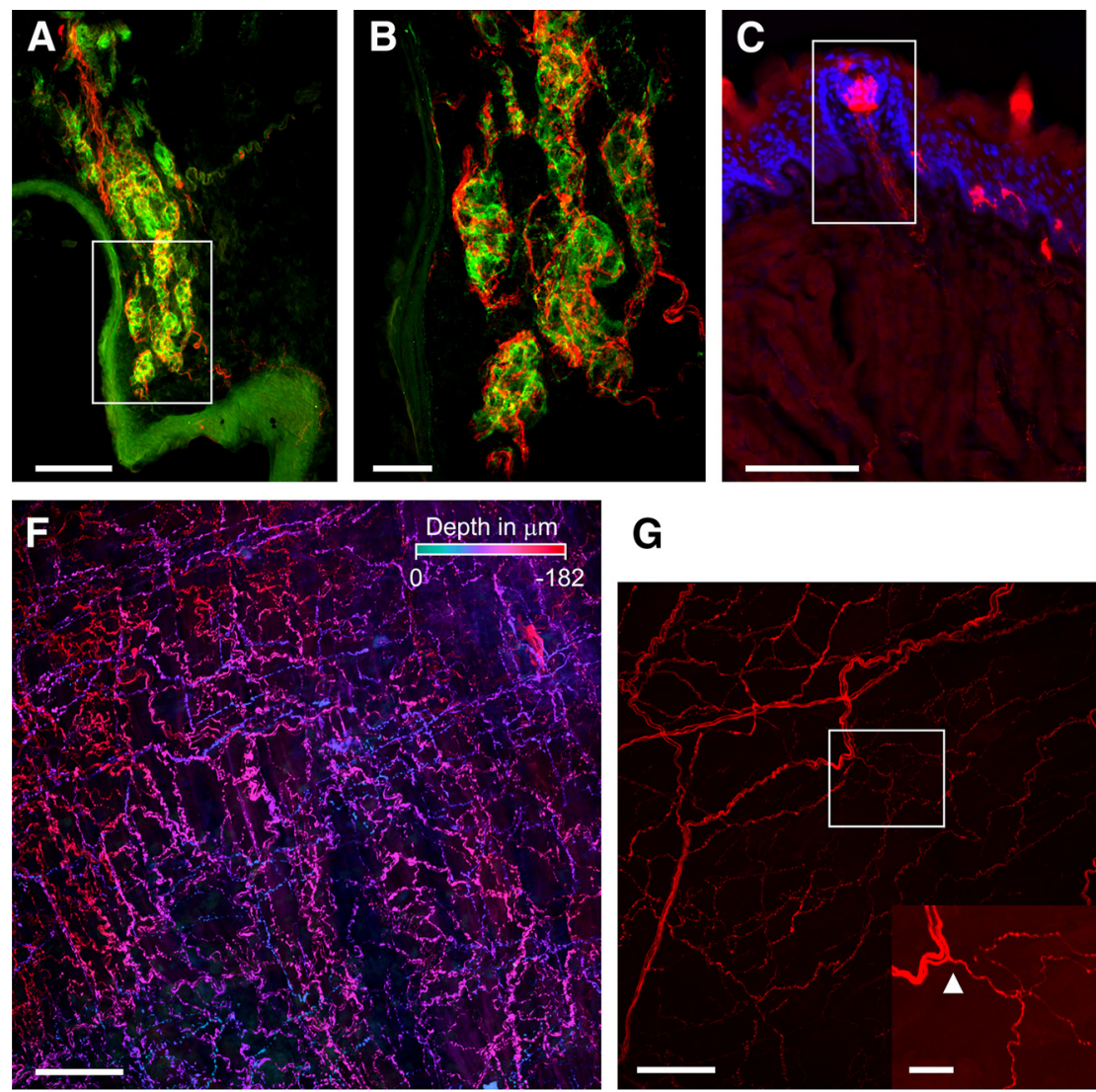

G

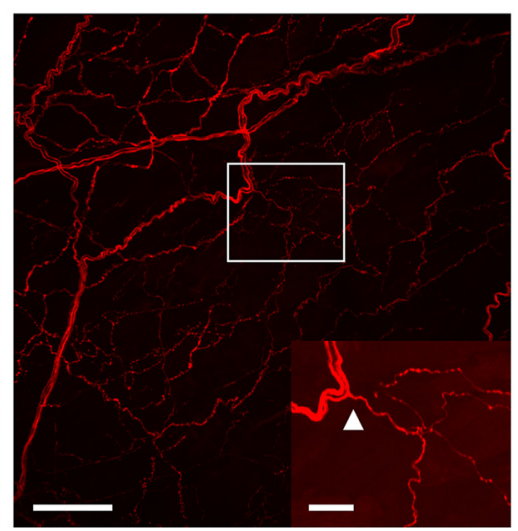

I

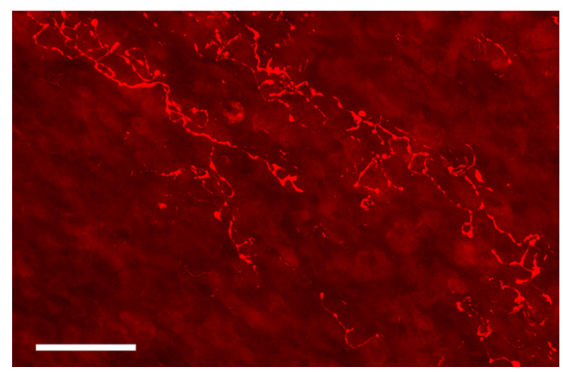

$\mathbf{J}$

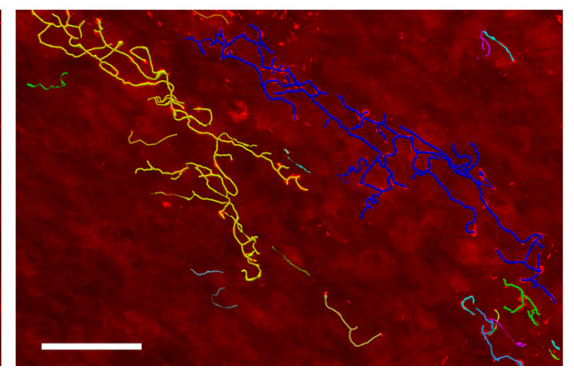

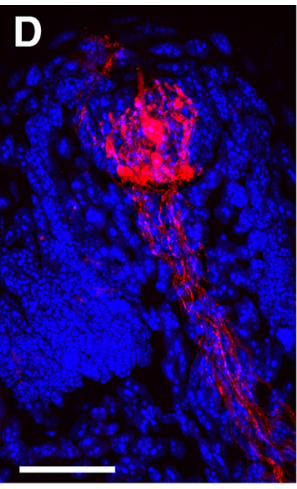

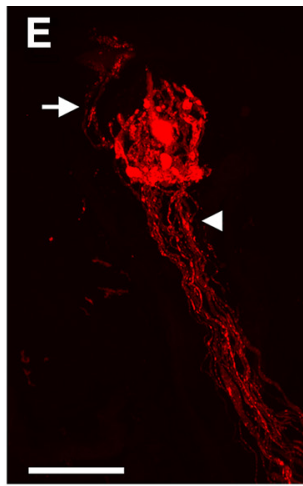

H
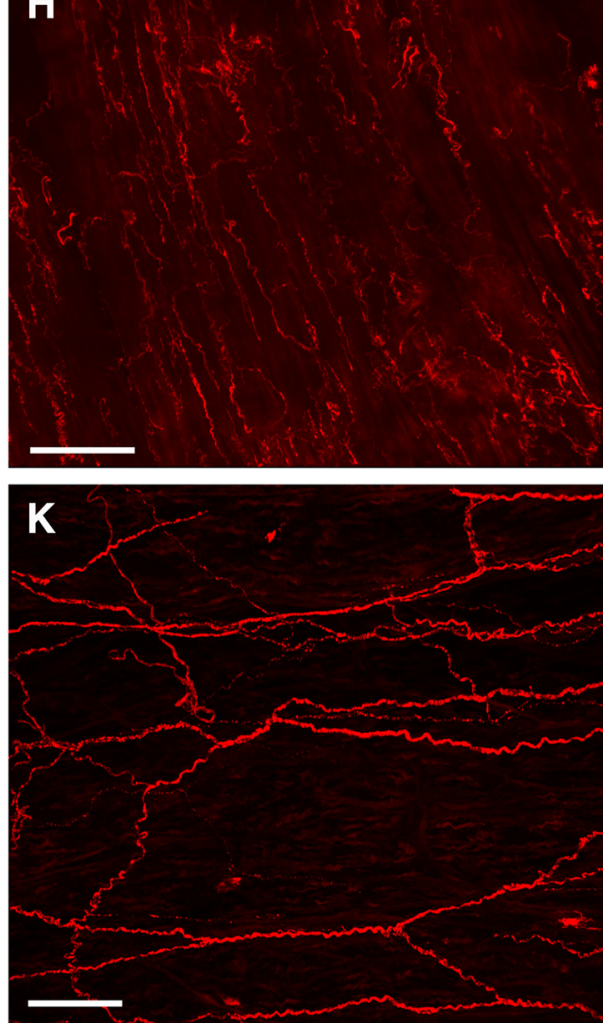

Figure 8. tdTomato expression in nerves innervating carotid bodies, taste buds, trachea, and esophagus of $\mathrm{P} 2 \mathrm{X}_{2}$-tdTomato mice. $\boldsymbol{A}$, Carotid body type 1 cells expressing TH (green) are innervated by nerves expressing tdTomato (red). $\boldsymbol{B}$, Higher magnification of area identified in $\boldsymbol{A}$. $\boldsymbol{C}-\boldsymbol{E}$, Taste bud on the surface of the tongue is innervated by nerves expressing tdTomato (red). DAPI staining (blue) identifies cell nuclei. $\boldsymbol{D}, \boldsymbol{E}$, Higher magnification of area identified in $\boldsymbol{C}$. Arrowhead denotes intragemmal fibers, arrow denotes perigemmal fiber. Note the expression of tdTomato in a subset of taste cells within the taste bud. F-J, tdTomato-expressing fibers throughout the epithelial, submucosal, trachealis muscle, and adventitial layers in a wholemount preparation of the trachea. $\boldsymbol{F}$, Complete $z$ projection, with tdTomato expression pseudocolor indicating the $z$ depth (total of $182 \mu \mathrm{m}$ ). $\mathbf{G}$, Extensive cabling of tdTomato-expressing fibers (red) in the adventitial layer with some of the muscle layer (63 $\mu \mathrm{m}$ in depth). Inset, Higher magnification of area identified in $\mathbf{G}$. Arrowhead highlights an example of a punctate multibranched fiber branching off a thick bundle of broad axons. $\boldsymbol{H}$, tdTomato-expressing fibers (red) innervating the trachealis muscle layer (25 $\mu \mathrm{m}$ in depth). $\boldsymbol{I}$, $\boldsymbol{J}$, tdTomato-expressing intraepithelial terminations (red) within the epithelial layer. Terminal arborizations were traced using Neurolucida software ( $\boldsymbol{J}$ ). $\boldsymbol{K}$, tdTomato-expressing fibers (red) in the submucosa and mucosal muscle layers in a wholemount preparation of the esophagus. Scale bars: $100 \mu \mathrm{m}(\boldsymbol{A}, \boldsymbol{C}, \boldsymbol{F}, \boldsymbol{G}, \boldsymbol{H}, \boldsymbol{I}, \boldsymbol{J}, \boldsymbol{K})$ and $30 \mu \mathrm{m}(\boldsymbol{B}, \boldsymbol{D}, \boldsymbol{E}, \boldsymbol{G}$, inset).

Lastly, we investigated the expression of tdTomato in the cochlea, based on reports that $\mathrm{P} 2 \mathrm{X}_{2}$ is important for purinergic-mediated adaptation and protection against noise-induced ototoxicity (Yan et al., 2013; Cederholm et al., 2019). We found robust expression of tdTomato in numerous specialized cells within the organ of Corti, including in the inner hair cells, outer hair cells, Deiters cells, Hensen's cells, and the outer pillar cells (Fig. 9). No tdTomato expression was noted in the basilar membrane. We also found tdTomato expression in the superficial interdental cells on the spiral limbus, and in some cells within the spiral ligament. Importantly, tdTomato was not 

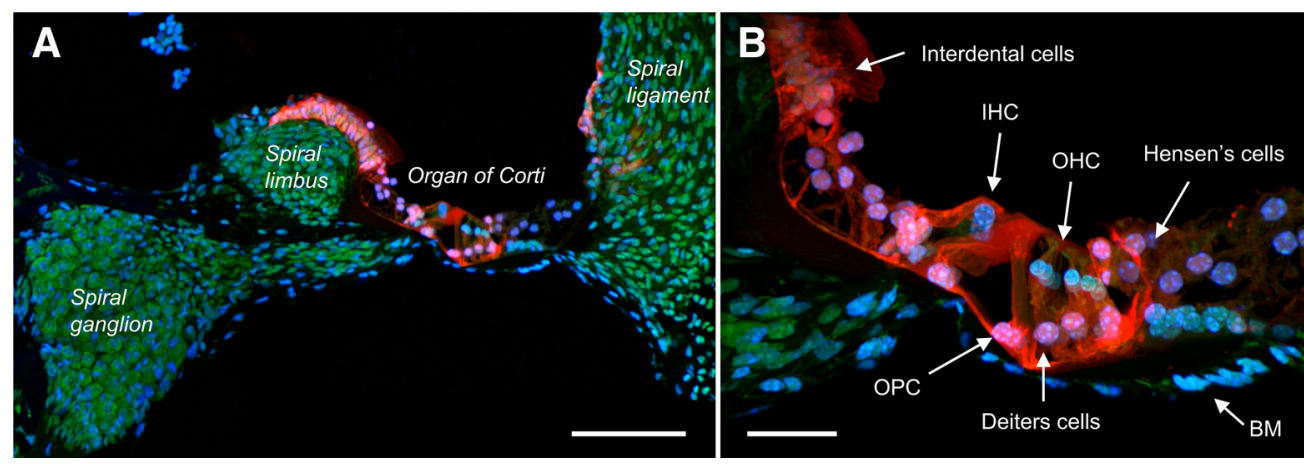

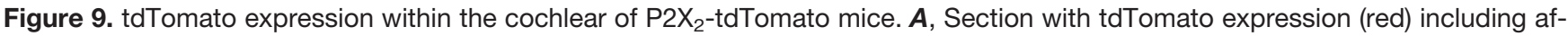
ferent cell bodies in the spiral ganglion, the spiral limbus, spiral ligament, and the organ of Corti, counterstained with NeuroTrace (green) and DAPI (blue). The tectorial membrane is missing from this section. $\boldsymbol{B}$, Higher magnification of the organ of Corti from $\boldsymbol{A}$. The following additional structures are identified: basilar membrane (BM), inner hair cells (IHC), outer hair cells (OHC), outer pillar cells (OPC). Scale bars: $100 \mu \mathrm{m}(\boldsymbol{A})$ and $30 \mu \mathrm{m}(\boldsymbol{B})$.

found in any spiral sensory neurons within the spiral ganglia, nor in their fibers that innervate the hair cells.

\section{Discussion}

$\mathrm{P} 2 \mathrm{X}_{2}$ expression has previously been assessed in multiple cell types using immunohistochemistry, in situ hybridization, RT-PCR, and functional sensitivity to ATP and other P2X ligands. Although it is generally agreed that $\mathrm{P} 2 \mathrm{X}_{2}$ is expressed on at least some peripheral afferent neurons, there is substantial disagreement regarding the precise details of its expression. Here, we have used a genetic approach, producing a knock-in $\mathrm{P} 2 \mathrm{X}_{2}{ }^{\text {Cre }}$ mouse that allows for the visualization of $\mathrm{P} 2 \mathrm{X}_{2}$ gene expression systematically. We replaced the endogenous $\mathrm{P}_{2} \mathrm{X}_{2}$ stop codon with a $2 \mathrm{~A}-\mathrm{Cre}$ cassette. $2 \mathrm{~A}$ is a self-cleaving peptide, thus expression of Cre recombinase peptides is expected to match $\mathrm{P} 2 \mathrm{X}_{2}$ peptide expression on a one-toone basis. This gene-targeted Cre expression system is more efficient than internal ribosome entry site (IRES) sequences (Furler et al., 2001; Gao et al., 2012) that have often been used in other knock-in Cre reporters.

The vagal ganglia are composed of nodose afferent neurons and jugular afferent neurons, both of which project sensory nerve terminals to multiple visceral organs. We found that almost all nodose neurons expressed tdTomato compared with almost none of the jugular neurons, thus indicating the selective expression of $\mathrm{P} 2 \mathrm{X}_{2}$ in the nodose portion of the vagal ganglia. Unlike in guinea pigs and larger mammals, the nodose and jugular ganglion are fused in mice. In these studies, we have, based on the idiosyncratic gross anatomy of each ganglion, subjectively assigned a hard line separating the nodose and jugular portions. This is likely an oversimplification of the distribution of nodose and jugular neurons, which are sometimes not perfectly delineated (Nassenstein et al., 2010; Surdenikova et al., 2012). As such, a small number of $\mathrm{P} 2 \mathrm{X}_{2}+$ and $\mathrm{P} 2 \mathrm{X}_{2}-$ neurons may have been inappropriately assigned. Overall, our data are consistent with single neuron RT-PCR and RNA-seq analysis of nodose and jugular neurons, which show that while $\mathrm{P} 2 \mathrm{X}_{3}$ is expressed by almost all vagal neurons, $\mathrm{P} 2 \mathrm{X}_{2}$ expression is restricted to nodose neurons (Kwong et al., 2008; Nassenstein et al.,
2010; Surdenikova et al., 2012; Wang et al., 2017; Trancikova et al., 2018; Kupari et al., 2019). ATP or $\alpha \beta$ mATP produces little to no activation of jugular afferents because of the rapid desensitization of homomeric $\mathrm{P} 2 \mathrm{X}_{3}$ channels, whereas these purinergic agonists evoke robust activation of dissociated nodose neurons and nodose peripheral terminals because of their persistent activation of heteromeric $\mathrm{P} 2 \mathrm{X}_{2 / 3}$ receptors (Undem et al., 2004; Yu et al., 2005; Kwong et al., 2008; Nassenstein et

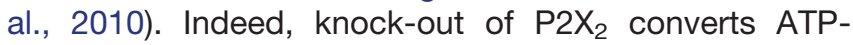
evoked currents in nodose neurons into rapidly desensitizing P2X $\mathrm{X}_{3}$-like currents (Cockayne et al., 2005). We found that $\mathrm{Ca}^{2+}$ influx responses to $\alpha \beta$ mATP in individual vagal neurons were correlated with tdTomato expression, confirming that the functional presence of $\mathrm{P}_{2} \mathrm{X}_{2}$-like responses was consistent with $\mathrm{P}_{2} \mathrm{X}_{2}$ reporter expression. $\mathrm{P} 2 \mathrm{X}_{2}$ expression was noted in both TRPV1 + and TRPV1nodose populations, consistent with previous studies (Undem et al., 2004; Kwong et al., 2008; Taylor-Clark et al., 2015).

Compared with the vagal ganglia, there is greater uncertainty regarding the expression of $P 2 X_{2}$ in the $D R G$ and trigeminal ganglia. $\mathrm{P} 2 \mathrm{X}_{2}$ immunoreactivity was reported to be in the majority of DRG neurons (Petruska et al., 2000b; Cockayne et al., 2005), and this immunoreactivity was absent in P2X 2 knock-out mice (Cockayne et al., 2005). Nevertheless, using mixed or persistent ATPevoked currents as a marker of $\mathrm{P} 2 \mathrm{X}_{2}$ expression, there are reports that $\mathrm{P} 2 \mathrm{X}_{2}$ expression ranges from $\sim 10 \%$ to $50 \%$ of DRG neurons (Cockayne et al., 2000, 2005; Dunn et al., 2000; Petruska et al., 2000a,b). Our data indicate that $\sim 12 \%$ of DRG neurons express $P 2 X_{2}$. This restricted expression is consistent with single neuron RT-PCR and RNA-seq analysis of DRG neurons (Kwong et al., 2008; Surdenikova et al., 2012; Usoskin et al., 2015; Trancikova et al., 2018; Hockley et al., 2019). P2X 2 immunoreactivity has also been reported to be in a large number of trigeminal neurons (Spehr et al., 2004; Ambalavanar et al., 2005; Simonetti et al., 2006; Staikopoulos et al., 2007). Mixed or persistent ATP-evoked currents have been noted in $~ 15-$ $75 \%$ of trigeminal neurons (Spehr et al., 2004; Damann et al., 2006; Luo et al., 2006; Simonetti et al., 2006; Liu et al., 
2015). Our data indicate that $\sim 4 \%$ trigeminal neurons express $\mathrm{P} 2 \mathrm{X}_{2}$. It is possible that $\mathrm{P} 2 \mathrm{X}_{2}$ 's contribution to "persistent" ATP-evoked currents in trigeminal neurons has been overestimated because of context-dependent P2X desensitization kinetics (Bianchi et al., 1999; Sokolova et al., 2006) and the contribution of other purinergic channels such as P2X1, P2X4, and P2X5, which are also expressed in trigeminal neurons (Kuroda et al., 2012; Liu et al., 2015).

Previous immunohistochemical and in situ hybridization studies have demonstrated widespread and robust $\mathrm{P}_{2} \mathrm{X}_{2}$ expression throughout the rodent CNS, including in the nTS, area postrema, ventrolateral medulla, medial vestibular nucleus, spinal trigeminal nucleus, hippocampus, hypothalamus, thalamus, striatum, substantia nigra, cerebellum, and cerebral cortex (Kidd et al., 1995; Collo et al., 1996; Vulchanova et al., 1996; Kanjhan et al., 1999; Yao et al., 2000, 2003; Gourine et al., 2003). However, based on the inconsistencies of previous $\mathrm{P} 2 \mathrm{X}_{2}$ detection in sensory ganglia, we briefly investigated the CNS expression of P2X with our reporter mouse. In general, we found P2X $\mathrm{X}_{2}$ expression in the CNS was limited compared with previous reports. Consistent with the widespread expression of tdTomato in nodose and petrosal neurons we found tdTomato-expressing central terminals within multiple subnuclei throughout the nTS and in the area postrema. Thus, $\mathrm{P} 2 \mathrm{X}_{2}$-expressing terminals target the same areas as terminals that express 5HT3 (another nodose neuronal marker that is expressed in very few jugular neurons; Kim et al., 2020). The nTS is the major target of vagal, geniculate, and petrosal ganglia afferents and is involved in reflex control of the cardiovascular, respiratory, and digestive systems. Consistent with the expression of tdTomato in few trigeminal neurons, there was little tdTomato expression in the spinal trigeminal nucleus or the paratrigeminal complex in the medulla. This distinguishes the $\mathrm{P} 2 \mathrm{X}_{2}$-tdTomato expression observed here from 5HT3-tdTomato expression, as $5 \mathrm{HT} 3$ is expressed in a large number of trigeminal afferents (Kim et al., 2020). This suggests that vagal terminations in the paratrigeminal complex (Driessen et al., 2015; McGovern et al., 2015; Kim et al., 2020), which may play a role in defensive reflexes from the airways, are exclusively via jugular afferents. There was limited tdTomato expression in the thoracic spinal cord, with the majority observed in fibers terminating in the superficial laminae of the dorsal horn. These are most likely to be the central projections of the limited number of DRG afferents that express $\mathrm{P} 2 \mathrm{X}_{2}$.

There was little tdTomato expression throughout the rest of the brainstem, with the exception of a subset of neurons in the pontine nucleus and lateral reticular nucleus, both of which project glutamatergic mossy fibers to the cerebellum (Kratochwil et al., 2017). In particular, we found only sparse P2X $\mathrm{X}_{2}$ expression in the intermediate/ caudal ventrolateral medulla and virtually no $\mathrm{P} 2 \mathrm{X}_{2}$ expression in the rostral ventrolateral medulla. Previous studies of ATP-evoked modulation of respiratory neurons within these regions have suggested that these actions correlated with $\mathrm{P} 2 \mathrm{X}_{2}$ immunoreactivity (Gourine et al., 2003; Yao et al., 2003). P2 $X_{2}$ expression in mossy fibers has been reported previously (Collo et al., 1996; Kanjhan et al., 1999), and these channels are thought to be distributed along the projections to the cerebellum (Florenzano et al., 2002). Indeed, we observed robust tdTomato expression in a large number of mossy fibers within the cerebellum. tdTomato expression was limited in other brain regions to very few neurons. Of note, we found few P2X $\mathrm{X}_{2}$ expressing neurons within the hippocampus, despite immunohistochemical and in situ hybridization studies identifying widespread $\mathrm{P} 2 \mathrm{X}_{2}$ expression in neurons within the CA1-3 and dentate gyrus (Kidd et al., 1995; Kanjhan et al., 1999), and a transgenic mouse model with a $P 2 X_{2}$ fusion protein with yellow fluorescent protein identifying P2X expression in hippocampal mossy fibers (Haustein et al., 2014).

We exploited the robust expression of tdTomato throughout $\mathrm{P} 2 \mathrm{X}_{2}$-expressing peripheral nerves to study their anatomy. As expected, glossopharyngeal afferents (projected from petrosal neurons) innervating the glomus type 1 cells in the carotid body expressed $\mathrm{P} 2 \mathrm{X}_{2}$. Type 1 cells are the principle peripheral chemoreceptors, and $\mathrm{P} 2 \mathrm{X}_{2}$ receptors are required for hypoxic signaling (although not $\mathrm{CO}_{2}$ detection) from the carotid body (Rong et al., 2003). The structural relationship between the $\mathrm{P} 2 \mathrm{X}_{2}$-expressing fibers and the type 1 cells is consistent with previous immunohistochemical studies (Yokoyama et al., 2019). Gustatory afferents innervating taste buds in the tongue expressed $\mathrm{P}_{2} \mathrm{X}_{2}$, consistent with the critical role of this receptor in taste cell-afferent signaling (Finger et al., 2005). Previous research has also shown P2X expression in taste buds using RT-PCR, and signaling of taste cell $\mathrm{P} 2 \mathrm{X}_{2}$ may act as autocrine, positive feedback signal to amplify taste-evoked ATP secretion (Huang et al., 2011). Our data suggest that $P 2 X_{2}$ expression occurs in only a subset of taste cells.

We investigated $\mathrm{P} 2 \mathrm{X}_{2}$-expressing terminals in the trachea and esophagus, which are likely projected from nodose neurons (Ricco et al., 1996; Yu et al., 2005; Kwong et al., 2008; Prescott et al., 2020). Previous studies of vagal afferent terminations in the mouse trachea using GFP expression following intraganglionic injections of an AAV-GFP construct have identified two classes of vagal afferents in the membranous area of the trachea: dorsal terminal structures that had fibers running largely in parallel to the smooth muscle but did not penetrate the epithelial layer, and small intraepithelial terminals (Hennel et al., 2018). Based on the similar morphology, it is likely that the $\mathrm{P} 2 \mathrm{X}_{2}$-expressing terminals observed in the trachea in the current study are a combination of dorsal terminal structures and small intraepithelial terminals, thus suggesting that these terminals are projected by nodose

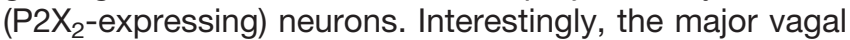
nerve terminal type found in the ligamentous part of the mouse trachea (termed "anterolateral segmental array") by Hennel et al. (2018) was not labeled in P2X $\mathrm{X}_{2}$-tdTomato mice, indicating that these probably originate from jugular neurons. Previous tracheal studies have identified A-fiber terminals with complex dendritic arbors innervating the epithelium and subepithelial layers over the cartilage rings in rats (Yamamoto and Nakamuta, 2018) and in the subepithelial layer over the ends of the cartilage rings in guinea pigs 
(Mazzone et al., 2009). Despite the fact that tracheal A-fibers are likely projected from nodose neurons (Mazzone et al., 2009), they were not detected in either the present study in P2X $\mathrm{X}_{2}$-tdTomato mice or in the AAV-GFP mouse study by Hennel et al. (2018), suggesting species differences in Afiber innervation of the trachea. This interpretation is somewhat complicated by the lack of $\alpha \beta$ mATP sensitivity in nodose $\mathrm{A} \delta$ fibers innervating the guinea pig trachea (Canning et al., 2004), suggesting that these nodose fibers surprisingly do not express $\mathrm{P}_{2} \mathrm{X}_{2}$. However, there are no published reports of $\mathrm{P} 2 \mathrm{X}_{2}$ expression in guinea pig nodose neurons labeled from the trachea, so definitive conclusions are not possible at this time. We also observed tdTomato-expressing fibers in the esophageal mucosa, which is innervated by nodose, jugular and DRG afferents (Yu et al., 2005; Surdenikova et al., 2012; Ru et al., 2015). Similar nerve structures were identified in the mouse esophageal mucosa following vagal intraganglionic injections of AAV-GFP (Harsanyiova et al., 2020). Thus, it is likely that the esophageal fibers identified here are projected by nodose ( $\left(\mathrm{P}_{2} \mathrm{X}_{2}-\mathrm{ex}-\right.$ pressing) neurons.

Lastly, we found evidence of $\mathrm{P} 2 \mathrm{X}_{2}$ expression in hair cells and their support cells within the organ of Corti in the cochlea. Previous studies have shown that both inner and outer hair cells express P2X $\mathrm{X}_{2}$, which mediate ATP-induced cationic currents (Housley et al., 1999; Järlebark et al., 2002). We found no expression of $P 2 X_{2}$ in the spiral ganglionic afferents that innervate the inner and outer hair cells, in disagreement with some immunohistochemical studies and dissociated patch clamp studies (Järlebark et al., 2002; Weisz et al., 2009; Ito and Dulon, 2010). Knockout of P2X $\mathrm{X}_{2}$ has no effect on auditory thresholds in nonaged mice (Yan et al., 2013), indicating that this channel is not critical to neurotransmission between the inner hair cells and the type 1 spiral afferents. Nevertheless, P2X knock-out accelerates noise-induced ototoxicity (Yan et al., 2013). Noise evokes local ATP release which causes P2 $\mathrm{X}_{2}$-mediated dampening of the cochlea amplifier by modifying the electromotility properties of the outer hair cells (Yu and Zhao, 2008; Housley et al., 2013; Cederholm et al., 2019). This paracrine humeral purinergic signaling is thought to complement the medial olivocochlear reflex suppression of the cochlear amplifier that is mediated by the type 2 spiral afferents that innervate the outer hair cells (Froud et al., 2015). Our observation of P2X $\mathrm{X}_{2}$ only in the hair cells and support cells is consistent with recent research that directly implicated the outer hair cell rather than the spiral afferents in the $\mathrm{P} 2 \mathrm{X}_{2}$-mediated pathways (Cederholm et al., 2019).

In summary, the $\mathrm{P} 2 \mathrm{X}_{2}$-cre reporter mouse demonstrates that $\mathrm{P} 2 \mathrm{X}_{2}$ expression is limited to subsets of neurons and specialized cells in the cochlea. Previous reports using biochemical techniques have overestimated the number of cell types that express $\mathrm{P} 2 \mathrm{X}_{2}$. This mouse provides a genetic approach to the identification and manipulation of $\mathrm{P} 2 \mathrm{X}_{2}$-expressing cell types. The current study used ROSA26-loxP-STOP-loxP-tdTomato mice to visualize cre-mediated recombination in the $\mathrm{P}_{2} \mathrm{X}_{2}$-cre-expressing cells. It should be noted that the excision of the loxPflanked stop region on cre expression is irreversible, thus
tdTomato expression cannot discriminate between transient and current $\mathrm{P} 2 \mathrm{X}_{2}$ expression in a given cell. It is possible that some of the tdTomato expression described here is because of transient $\mathrm{P} 2 \mathrm{X}_{2}$ expression.

\section{References}

Ambalavanar R, Moritani M, Dessem D (2005) Trigeminal P2X3 receptor expression differs from dorsal root ganglion and is modulated by deep tissue inflammation. Pain 117:280-291.

Bianchi BR, Lynch KJ, Touma E, Niforatos W, Burgard EC, Alexander KM, Park HS, Yu H, Metzger R, Kowaluk E, Jarvis MF, van Biesen T (1999) Pharmacological characterization of recombinant human and rat $\mathrm{P} 2 \mathrm{X}$ receptor subtypes. Eur $\mathrm{J}$ Pharmacol 376:127-138.

Brake AJ, Wagenbach MJ, Julius D (1994) New structural motif for ligand-gated ion channels defined by an ionotropic ATP receptor. Nature 371:519-523.

Canning BJ, Mazzone SB, Meeker SN, Mori N, Reynolds SM, Undem BJ (2004) Identification of the tracheal and laryngeal afferent neurones mediating cough in anaesthetized guinea-pigs. J Physiol 557:543-558.

Cederholm JME, Ryan AF, Housley GD (2019) Onset kinetics of noise-induced purinergic adaptation of the 'cochlear amplifier'. Purinergic Signal 15:343-355.

Chen CC, Akopian AN, Sivilotti L, Colquhoun D, Burnstock G, Wood JN (1995) A P2X purinoceptor expressed by a subset of sensory neurons. Nature 377:428-431.

Cockayne DA, Hamilton SG, Zhu QM, Dunn PM, Zhong Y, Novakovic S, Malmberg AB, Cain G, Berson A, Kassotakis L, Hedley L, Lachnit WG, Burnstock G, McMahon SB, Ford AP (2000) Urinary bladder hyporeflexia and reduced pain-related behaviour in P2X3-deficient mice. Nature 407:1011-1015.

Cockayne DA, Dunn PM, Zhong Y, Rong W, Hamilton SG, Knight GE, Ruan HZ, Ma B, Yip P, Nunn P, McMahon SB, Burnstock G, Ford AP (2005) P2X2 knockout mice and P2X2/P2X3 double knockout mice reveal a role for the P2X2 receptor subunit in mediating multiple sensory effects of ATP. J Physiol 567:621-639.

Collo G, North RA, Kawashima E, Merlo-Pich E, Neidhart S, Surprenant A, Buell G (1996) Cloning of P2X5 and P2X6 receptors and the distribution and properties of an extended family of ATPgated ion channels. J Neurosci 16:2495-2507.

Damann N, Rothermel M, Klupp BG, Mettenleiter TC, Hatt H, Wetzel $\mathrm{CH}$ (2006) Chemosensory properties of murine nasal and cutaneous trigeminal neurons identified by viral tracing. BMC Neurosci 7:46.

Dickstein DL, Dickstein DR, Janssen WG, Hof PR, Glaser JR, Rodriguez A, O'Connor N, Angstman P, Tappan SJ (2016) Automatic dendritic spine quantification from confocal data with Neurolucida 360. Curr Protoc Neurosci 77:1.27.1-21.27.21.

Driessen AK, Farrell MJ, Mazzone SB, McGovern AE (2015) The role of the paratrigeminal nucleus in vagal afferent evoked respiratory reflexes: a neuroanatomical and functional study in guinea pigs. Front Physiol 6:378.

Dunn PM, Liu M, Zhong Y, King BF, Burnstock G (2000) Diinosine pentaphosphate: an antagonist which discriminates between recombinant $\mathrm{P} 2 \mathrm{X}(3)$ and $\mathrm{P} 2 \mathrm{X}(2 / 3)$ receptors and between two $\mathrm{P} 2 \mathrm{X}$ receptors in rat sensory neurones. Br J Pharmacol 130:13781384.

Dunn PM, Zhong Y, Burnstock G (2001) P2X receptors in peripheral neurons. Prog Neurobiol 65:107-134.

Finger TE, Danilova V, Barrows J, Bartel DL, Vigers AJ, Stone L, Hellekant G, Kinnamon SC (2005) ATP signaling is crucial for communication from taste buds to gustatory nerves. Science 310:1495-1499.

Florenzano F, Viscomi MT, Cavaliere F, Volonté C, Molinari M (2002) Cerebellar lesion up-regulates $\mathrm{P} 2 \mathrm{X} 1$ and $\mathrm{P} 2 \mathrm{X} 2$ purinergic receptors in precerebellar nuclei. Neuroscience 115:425-434. 
Froud KE, Wong AC, Cederholm JM, Klugmann M, Sandow SL, Julien JP, Ryan AF, Housley GD (2015) Type II spiral ganglion afferent neurons drive medial olivocochlear reflex suppression of the cochlear amplifier. Nat Commun 6:7115.

Furler S, Paterna JC, Weibel M, Büeler H (2001) Recombinant AAV vectors containing the foot and mouth disease virus $2 \mathrm{~A}$ sequence confer efficient bicistronic gene expression in cultured cells and rat substantia nigra neurons. Gene Ther 8:864-873.

Gao SY, Jack MM, O'Neill C (2012) Towards optimising the production of and expression from polycistronic vectors in embryonic stem cells. PLoS One 7:e48668.

Gourine AV, Atkinson L, Deuchars J, Spyer KM (2003) Purinergic signalling in the medullary mechanisms of respiratory control in the rat: respiratory neurones express the P2X2 receptor subunit. $J$ Physiol 552:197-211.

Harsanyiova J, Ru F, Zatko T, Kollarik M, Hennel M (2020) Vagus nerves provide a robust afferent innervation of the mucosa throughout the body of the esophagus in the mouse. Dysphagia 35:471-478.

Haustein MD, Kracun S, Lu XH, Shih T, Jackson-Weaver O, Tong X, Xu J, Yang XW, O'Dell TJ, Marvin JS, Ellisman MH, Bushong EA, Looger LL, Khakh BS (2014) Conditions and constraints for astrocyte calcium signaling in the hippocampal mossy fiber pathway. Neuron 82:413-429.

Hennel M, Harsanyiova J, Ru F, Zatko T, Brozmanova M, Trancikova A, Tatar M, Kollarik M (2018) Structure of vagal afferent nerve terminal fibers in the mouse trachea. Respir Physiol Neurobiol 249:35-46.

Hockley JRF, Taylor TS, Callejo G, Wilbrey AL, Gutteridge A, Bach K, Winchester WJ, Bulmer DC, McMurray G, Smith ESJ (2019) Single-cell RNAseq reveals seven classes of colonic sensory neuron. Gut 68:633-644.

Housley GD, Kanjhan R, Raybould NP, Greenwood D, Salih SG, Järlebark L, Burton LD, Setz VC, Cannell MB, Soeller C, Christie DL, Usami S, Matsubara A, Yoshie H, Ryan AF, Thorne PR (1999) Expression of the P2X(2) receptor subunit of the ATP-gated ion channel in the cochlea: implications for sound transduction and auditory neurotransmission. J Neurosci 19:8377-8388.

Housley GD, Morton-Jones R, Vlajkovic SM, Telang RS, Paramananthasivam V, Tadros SF, Wong AC, Froud KE, Cederholm JM, Sivakumaran Y, Snguanwongchai P, Khakh BS, Cockayne DA, Thorne PR, Ryan AF (2013) ATP-gated ion channels mediate adaptation to elevated sound levels. Proc Natl Acad Sci USA 110:7494-7499.

Huang YA, Stone LM, Pereira E, Yang R, Kinnamon JC, Dvoryanchikov G, Chaudhari N, Finger TE, Kinnamon SC, Roper SD (2011) Knocking out P2X receptors reduces transmitter secretion in taste buds. J Neurosci 31:13654-13661.

Ito K, Dulon D (2010) Purinergic signaling in cochleovestibular hair cells and afferent neurons. Purinergic Signal 6:201-209.

Järlebark LE, Housley GD, Raybould NP, Vlajkovic S, Thorne PR (2002) ATP-gated ion channels assembled from P2X2 receptor subunits in the mouse cochlea. Neuroreport 13:1979-1984.

Kanjhan R, Housley GD, Burton LD, Christie DL, Kippenberger A, Thorne PR, Luo L, Ryan AF (1999) Distribution of the P2X2 receptor subunit of the ATP-gated ion channels in the rat central nervous system. J Comp Neurol 407:11-32.

Khakh BS, Burnstock G, Kennedy C, King BF, North RA, Séguéla P, Voigt M, Humphrey PP (2001) International union of pharmacology. XXIV. Current status of the nomenclature and properties of P2X receptors and their subunits. Pharmacol Rev 53:107-118.

Kidd EJ, Grahames CB, Simon J, Michel AD, Barnard EA, Humphrey PP (1995) Localization of P2X purinoceptor transcripts in the rat nervous system. Mol Pharmacol 48:569-573.

Kim SH, Hadley SH, Maddison M, Patil M, Cha BJ, Kollarik M, Taylor-Clark TE (2020) Mapping of sensory nerve subsets within the vagal ganglia and the brainstem using reporter mice for Pirt, TRPV1, 5-HT3 and Tac1 expression. eNeuro 7.
Kratochwil CF, Maheshwari U, Rijli FM (2017) The long journey of pontine nuclei neurons: from rhombic lip to cortico-ponto-cerebellar circuitry. Front Neural Circuits 11:33.

Kubin L, Kimura H, Davies RO (1991) The medullary projections of afferent bronchopulmonary $\mathrm{C}$ fibres in the cat as shown by antidromic mapping. J Physiol 435:207-228.

Kubin L, Alheid GF, Zuperku EJ, McCrimmon DR (2006) Central pathways of pulmonary and lower airway vagal afferents. J Appl Physiol 101:618-627.

Kupari J, Häring M, Agirre E, Castelo-Branco G, Ernfors P (2019) An atlas of vagal sensory neurons and their molecular specialization. Cell Rep 27:2508-2523.e4.

Kuroda H, Shibukawa Y, Soya M, Masamura A, Kasahara M, Tazaki $\mathrm{M}$, Ichinohe $\mathrm{T}$ (2012) Expression of $\mathrm{P} 2 \mathrm{X}(1)$ and $\mathrm{P} 2 \mathrm{X}(4)$ receptors in rat trigeminal ganglion neurons. Neuroreport 23:752-756.

Kwong K, Kollarik M, Nassenstein C, Ru F, Undem BJ (2008) P2X2 receptors differentiate placodal vs neural crest $C$-fiber phenotypes innervating guinea pig lungs and esophagus. Am J Physiol Lung Cell Mol Physiol 295:L858-L865.

Lewis C, Neidhart S, Holy C, North RA, Buell G, Surprenant A (1995) Coexpression of $\mathrm{P} 2 \mathrm{X} 2$ and $\mathrm{P} 2 \mathrm{X} 3$ receptor subunits can account for ATP-gated currents in sensory neurons. Nature 377:432-435.

Liu M, King BF, Dunn PM, Rong W, Townsend-Nicholson A, Burnstock G (2001) Coexpression of P2X(3) and P2X(2) receptor subunits in varying amounts generates heterogeneous populations of $\mathrm{P} 2 \mathrm{X}$ receptors that evoke a spectrum of agonist responses comparable to that seen in sensory neurons. J Pharmacol Exp Ther 296:1043-1050.

Liu Y, Tian X, Wu Y, Chen L, Yi CL, Li ZW, Zhang Y, Li CY (2015) Phenotypes of ATP-activated current associated with their genotypes of P2X1-6 subunits in neurons innervating tooth-pulp. Biochem Biophys Res Commun 458:596-600.

Luo J, Yin GF, Gu YZ, Liu Y, Dai JP, Li C, Li ZW (2006) Characterization of three types of ATP-activated current in relation to $\mathrm{P} 2 \mathrm{X}$ subunits in rat trigeminal ganglion neurons. Brain Res 1115:9-15.

Mazzone SB, Undem BJ (2016) Vagal afferent innervation of the airways in health and disease. Physiol Rev 96:975-1024.

Mazzone SB, Reynolds SM, Mori N, Kollarik M, Farmer DG, Myers AC, Canning BJ (2009) Selective expression of a sodium pump isozyme by cough receptors and evidence for its essential role in regulating cough. J Neurosci 29:13662-13671.

McCord JL, Tsuchimochi H, Kaufman MP (2010) P2X2/3 and P2X3 receptors contribute to the metaboreceptor component of the exercise pressor reflex. J Appl Physiol (1985) 109:1416-1423.

McGovern AE, Driessen AK, Simmons DG, Powell J, Davis-Poynter N, Farrell MJ, Mazzone SB (2015) Distinct brainstem and forebrain circuits receiving tracheal sensory neuron inputs revealed using a novel conditional anterograde transsynaptic viral tracing system. $J$ Neurosci 35:7041-7055.

Nassenstein C, Taylor-Clark TE, Myers AC, Ru F, Nandigama R, Bettner W, Undem BJ (2010) Phenotypic distinctions between neural crest and placodal derived vagal C-fibres in mouse lungs. J Physiol 588:4769-4783.

Paxinos G, Franklin B (2012) Mouse brain in stereotaxic coordinates, Ed 4. San Diego: Elsevier.

Petruska JC, Cooper BY, Johnson RD, Gu JG (2000a) Distribution patterns of different $\mathrm{P} 2 \mathrm{x}$ receptor phenotypes in acutely dissociated dorsal root ganglion neurons of adult rats. Exp Brain Res 134:126-132.

Petruska JC, Cooper BY, Gu JG, Rau KK, Johnson RD (2000b) Distribution of P2X1, P2X2, and $\mathrm{P} 2 \mathrm{X} 3$ receptor subunits in rat primary afferents: relation to population markers and specific cell types. J Chem Neuroanat 20:141-162.

Prescott SL, Umans BD, Williams EK, Brust RD, Liberles SD (2020) An airway protection program revealed by sweeping genetic control of vagal afferents. Cell 181:574-589.e4.

Ricco MM, Kummer W, Biglari B, Myers AC, Undem BJ (1996) Interganglionic segregation of distinct vagal afferent fibre phenotypes in guinea-pig airways. J Physiol 496:521-530. 
Rong W, Gourine AV, Cockayne DA, Xiang Z, Ford AP, Spyer KM, Burnstock G (2003) Pivotal role of nucleotide P2X2 receptor subunit of the ATP-gated ion channel mediating ventilatory responses to hypoxia. J Neurosci 23:11315-11321.

Ru F, Banovcin P Jr, Kollarik M (2015) Acid sensitivity of the spinal dorsal root ganglia C-fiber nociceptors innervating the guinea pig esophagus. Neurogastroenterol Motil 27:865-874.

Simonetti M, Fabbro A, D'Arco M, Zweyer M, Nistri A, Giniatullin R, Fabbretti E (2006) Comparison of P2X and TRPV1 receptors in ganglia or primary culture of trigeminal neurons and their modulation by NGF or serotonin. Mol Pain 2:11.

Sokolova E, Skorinkin A, Moiseev I, Agrachev A, Nistri A, Giniatullin $R$ (2006) Experimental and modeling studies of desensitization of P2X3 receptors. Mol Pharmacol 70:373-382.

Song X, Gao X, Guo D, Yu Q, Guo W, He C, Burnstock G, Xiang Z (2012) Expression of P2X(2) and P2X (3) receptors in the rat carotid sinus, aortic arch, vena cava, and heart, as well as petrosal and nodose ganglia. Purinergic Signal 8:15-22.

Spehr J, Spehr M, Hatt H, Wetzel CH (2004) Subunit-specific P2X-receptor expression defines chemosensory properties of trigeminal neurons. Eur J Neurosci 19:2497-2510.

Staikopoulos V, Sessle BJ, Furness JB, Jennings EA (2007) Localization of $\mathrm{P} 2 \mathrm{X} 2$ and $\mathrm{P} 2 \mathrm{X} 3$ receptors in rat trigeminal ganglion neurons. Neuroscience 144:208-216.

Stanford KR, Taylor-Clark TE (2018) Mitochondrial modulation-induced activation of vagal sensory neuronal subsets by antimycin $\mathrm{A}$, but not CCCP or rotenone, correlates with mitochondrial superoxide production. PLoS One 13:e0197106.

Stanford KR, Hadley SH, Barannikov I, Ajmo JM, Bahia PK, TaylorClark TE (2019) Antimycin A-induced mitochondrial dysfunction activates vagal sensory neurons via ROS-dependent activation of TRPA1 and ROS-independent activation of TRPV1. Brain Res 1715:94-105.

Surdenikova L, Ru F, Nassenstein C, Tatar M, Kollarik M (2012) The neural crest- and placodes-derived afferent innervation of the mouse esophagus. Neurogastroenterol Motil 24:e517-e525.

Taylor-Clark TE, Wu KY, Thompson JA, Yang K, Bahia PK, Ajmo JM (2015) Thy1.2 YFP-16 transgenic mouse labels a subset of largediameter sensory neurons that lack TRPV1 expression. PLoS One 10:e0119538.

Trancikova A, Kovacova E, Ru F, Varga K, Brozmanova M, Tatar M, Kollarik M (2018) Distinct expression of phenotypic markers in placodes- and neural crest-derived afferent neurons innervating the rat stomach. Dig Dis Sci 63:383-394.

Undem BJ, Chuaychoo B, Lee MG, Weinreich D, Myers AC, Kollarik M (2004) Subtypes of vagal afferent C-fibres in guinea-pig lungs. J Physiol 556:905-917.

Usoskin D, Furlan A, Islam S, Abdo H, Lönnerberg P, Lou D, HjerlingLeffler J, Haeggström J, Kharchenko O, Kharchenko PV,
Linnarsson S, Ernfors P (2015) Unbiased classification of sensory neuron types by large-scale single-cell RNA sequencing. Nat Neurosci 18:145-153.

Vulchanova L, Arvidsson U, Riedl M, Wang J, Buell G, Surprenant A, North RA, Elde R (1996) Differential distribution of two ATP-gated channels (P2X receptors) determined by immunocytochemistry. Proc Natl Acad Sci USA 93:8063-8067.

Wang J, Kollarik M, Ru F, Sun H, McNeil B, Dong X, Stephens G, Korolevich S, Brohawn P, Kolbeck R, Undem B (2017) Distinct and common expression of receptors for inflammatory mediators in vagal nodose versus jugular capsaicin-sensitive/TRPV1-positive neurons detected by low input RNA sequencing. PLoS One 12: e0185985.

Weigand LA, Ford AP, Undem BJ (2012) A role for ATP in bronchoconstriction-induced activation of guinea pig vagal intrapulmonary C-fibres. J Physiol 590:4109-4120.

Weisz C, Glowatzki E, Fuchs P (2009) The postsynaptic function of type II cochlear afferents. Nature 461:1126-1129.

Yamamoto Y, Nakamuta N (2018) Morphology of P2X3-immunoreactive nerve endings in the rat tracheal mucosa. J Comp Neurol 526:550-566.

Yan D, Zhu Y, Walsh T, Xie D, Yuan H, Sirmaci A, Fujikawa T, Wong ACY, Loh TL, Du L, Grati M, Vlajkovic SM, Blanton S, Ryan AF, Chen ZY, Thorne PR, Kachar B, Tekin M, Zhao HB, Housley GD, et al. (2013) Mutation of the ATP-gated P2X(2) receptor leads to progressive hearing loss and increased susceptibility to noise. Proc Natl Acad Sci USA 110:2228-2233.

Yao ST, Barden JA, Finkelstein DI, Bennett MR, Lawrence AJ (2000) Comparative study on the distribution patterns of P2X(1)-P2X(6) receptor immunoreactivity in the brainstem of the rat and the common marmoset (Callithrix jacchus): association with catecholamine cell groups. J Comp Neurol 427:485-507.

Yao ST, Gourine AV, Spyer KM, Barden JA, Lawrence AJ (2003) Localisation of $\mathrm{P} 2 \mathrm{X} 2$ receptor subunit immunoreactivity on nitric oxide synthase expressing neurones in the brain stem and hypothalamus of the rat: a fluorescence immunohistochemical study. Neuroscience 121:411-419.

Yokoyama T, Settai K, Nakamuta N, Yamamoto Y (2019) Distribution and morphology of baroreceptors in the rat carotid sinus as revealed by immunohistochemistry for P2X3 purinoceptors. Histochem Cell Biol 151:161-173.

Yu N, Zhao HB (2008) ATP activates P2x receptors and requires extracellular $\mathrm{Ca}(++)$ participation to modify outer hair cell nonlinear capacitance. Pflugers Arch 457:453-461.

Yu S, Undem BJ, Kollarik M (2005) Vagal afferent nerves with nociceptive properties in guinea-pig oesophagus. J Physiol 563:831842. 